\title{
Transgenic Wheat Harboring an RNAi Element Confers Dual Resistance Against Synergistically Interacting Wheat Streak Mosaic Virus and Triticum Mosaic Virus
}

\author{
Satyanarayana Tatineni, ${ }^{1,+}$ Shirley Sato, ${ }^{2}$ Natalya Nersesian, ${ }^{2}$ Jeff Alexander, ${ }^{3}$ Truyen Quach, ${ }^{4}$ \\ Robert A Graybosch, ${ }^{3}$ and Tom Elmo Clemente ${ }^{4,5}$ \\ ${ }^{1}$ United States Department of Agriculture-Agricultural Research Service (USDA-ARS) and Department of Plant Pathology, \\ University of Nebraska-Lincoln, Lincoln, NE 68583, U.S.A. \\ ${ }^{2}$ Center for Biotechnology, University of Nebraska-Lincoln \\ ${ }^{3}$ USDA-ARS, University of Nebraska-Lincoln \\ ${ }^{4}$ Department of Agronomy \& Horticulture, University of Nebraska-Lincoln \\ ${ }^{5}$ Center for Plant Science Innovation, University of Nebraska-Lincoln
}

Accepted 1 November 2019.

\begin{abstract}
Wheat streak mosaic virus (WSMV) and triticum mosaic virus (TriMV) are economically important viruses of wheat (Triticum aestivum L.), causing significant yield losses in the Great Plains region of the United States. These two viruses are transmitted by wheat curl mites, which often leads to mixed infections with synergistic interaction in grower fields that exacerbates yield losses. Development of dual-resistant wheat lines would provide effective control of these two viruses. In this study, a genetic resistance strategy employing an RNA interference (RNAi) approach was implemented by assembling a hairpin element composed of a 202-bp (404-bp in total) stem sequence of the NIb (replicase) gene from each of WSMV and TriMV in tandem and of an intron sequence in the loop. The derived RNAi element was cloned into a binary vector and was used to transform spring wheat genotype CB037. Phenotyping of $T_{1}$ lineages across eight independent transgenic events for resistance revealed that $i)$ two of the transgenic events provided resistance to WSMV and TriMV, ii) four events provided resistance to either WSMV or TriMV, and iii) no resistance was found in two other events. $T_{2}$ populations derived from the two events classified as dual-resistant were subsequently monitored for stability of the resistance phenotype through the $T_{4}$ generation. The resistance phenotype in these events was temperature-dependent, with a complete dual resistance at temperatures $\geq 25^{\circ} \mathrm{C}$ and an increasingly susceptible response at temperatures below $25^{\circ} \mathrm{C}$. Northern blot hybridization of total RNA from transgenic wheat revealed that virus-specific small RNAs (vsRNAs) accumulated progressively with an increase in temperature, with no detectable levels of vsRNA accumulation at $20^{\circ} \mathrm{C}$. Thus, the resistance phenotype of wheat
\end{abstract}

${ }^{\dagger}$ Corresponding author: S. Tatineni; satyanarayana.tatineni@usda.gov

Funding: This research was funded by the United States Department of Agriculture Agricultural Research Service Current Research Information System (5440-21000-033-00D) and in part supported by a research grant from the Nebraska Wheat Board.

The author(s) declare no conflict of interest.

This article is in the public domain and not copyrightable. It may be freely reprinted with customary crediting of the source. The American Phytopathological Society, 2020. harboring an RNAi element was correlated with accumulation of vsRNAs, and the generation of vsRNAs can be used as a molecular marker for the prediction of resistant phenotypes of transgenic plants at a specific temperature.

Keywords: dual resistance, RNA interference, RNAi, synergistic interaction, transgenic wheat, triticum mosaic virus, vsRNAs, wheat, wheat streak mosaic virus

Wheat streak mosaic virus (WSMV) is the most economically important virus infecting wheat (Triticum aestivum L.) in the Great Plains region of the United States (French and Stenger 2004). The wheat streak mosaic disease complex, caused by WSMV, triticum mosaic virus (TriMV), and High Plains wheat mosaic virus, was the second most important disease of wheat in 2017 in Kansas, with a 5.6\% estimated yield loss (Hollandbeck et al. 2017). Occasionally, nearly $100 \%$ yield loss can occur in localized infections (Brakke 1987; French and Stenger 2004; Hollandbeck et al. 2017). TriMV was first documented in Kansas in the wheat cultivar RonL in 2006 (Seifers et al. 2008), and the virus was subsequently spread throughout the Great Plains region (Burrows et al. 2009). Though the impact of TriMV on wheat yield has not been fully assessed, recent reports recognized its potential for significant yield losses (Byamukama et al. 2013; Seifers et al. 2011). WSMV and TriMV are transmitted by the wheat curl mite Aceria tosichella Keifer (McMechan et al. 2014; Seifers et al. 2009; Slykhuis 1955). Since both viruses are transmitted by a common vector, coinfection of wheat by WSMV and TriMV is common in grower fields (Byamukama et al. 2013). WSMV and TriMV synergistically interact in wheat, resulting in more severe disease symptoms and exacerbated yield losses compared with single infections (Byamukama et al. 2012; Tatineni et al. 2010). TriMV occurs in winter wheat predominantly as coinfection with WSMV (Byamukama et al. 2013), which can complicate a breeding strategy for resistance that targets the vector wheat curl mite. Additionally, coinfection of susceptible maize cultivars by WSMV and maize chlorotic mottle virus cause disease synergism with enhanced disease severity (Stenger et al. 2007).

WSMV and TriMV are the type species of the genera Tritimovirus and Poacevirus, respectively, in the family Potyviridae (Stenger et al. 1998; Tatineni et al. 2009). The flexuous 
filamentous virion particles of WSMV and TriMV contain a single 9.4- and 10.3-kb genomic RNA, respectively (Fig. 1A). The genomic organization of both viruses is similar, a single large open reading frame that encodes for approximately 350 $\mathrm{kDa}$ polyproteins (Fig. 1A). The polyproteins of both viruses are processed into at least 10 mature proteins, analogous to potyviruses, by three virus-encoded proteinases (P1, HC-Pro, and NIa-Pro).

Plants utilize RNA silencing- or RNA interference (RNAi)based host defense mechanisms to combat infections against viruses (Baulcombe 2004; Ding 2010; Qu 2010). The doublestranded (ds)RNA molecules produced during the replication of viruses trigger Dicer-like class III RNases to cleave the dsRNAs into small 21- to 24-nt RNA complexes (Ding and Voinnet 2007; Hamilton and Baulcombe 1999). These small RNAs along with Argonaute proteins form the RNA-induced silencing complex to degrade the incoming homologous viral RNA molecules in a sequence-specific manner (Hammond et al. 2000). Most plant viruses encode suppressors of RNA silencing to overcome host-induced RNAi defense mechanisms (Csorba et al. 2015). However, plants can gain a competitive edge in a tug-of-war with virus invasion when programed with constitutively produced virus-specific small RNAs (vsRNAs) (Ding 2010; Waterhouse et al. 1998). The vsRNAs can be generated by in planta expression of portions of viral genomic RNA in sense and antisense orientations to generate hairpinlike dsRNAs (hpRNAs). These hpRNAs will be cleaved posttranscriptionally into vsRNAs by the plant defense machinery (Wesley et al. 2001). An efficient way to produce dsRNAs is the use of 200- to 500-nt-long inverted-repeat constructs to form hpRNA (Wesley et al. 2001). The hpRNA constructs generally result in high levels of resistance against homologous viruses (Eamens et al. 2008; Gaffar and Koch 2019).

Plant viral diseases are controlled by cultural practices, genetic resistance, and pathogen-derived resistance to a limited extent (Jones 2006). Recently, genetic resistance in wheat has been used for the management of viral diseases through deployment of nonallelic Wsml or Wsm2 genes (Graybosch et al.
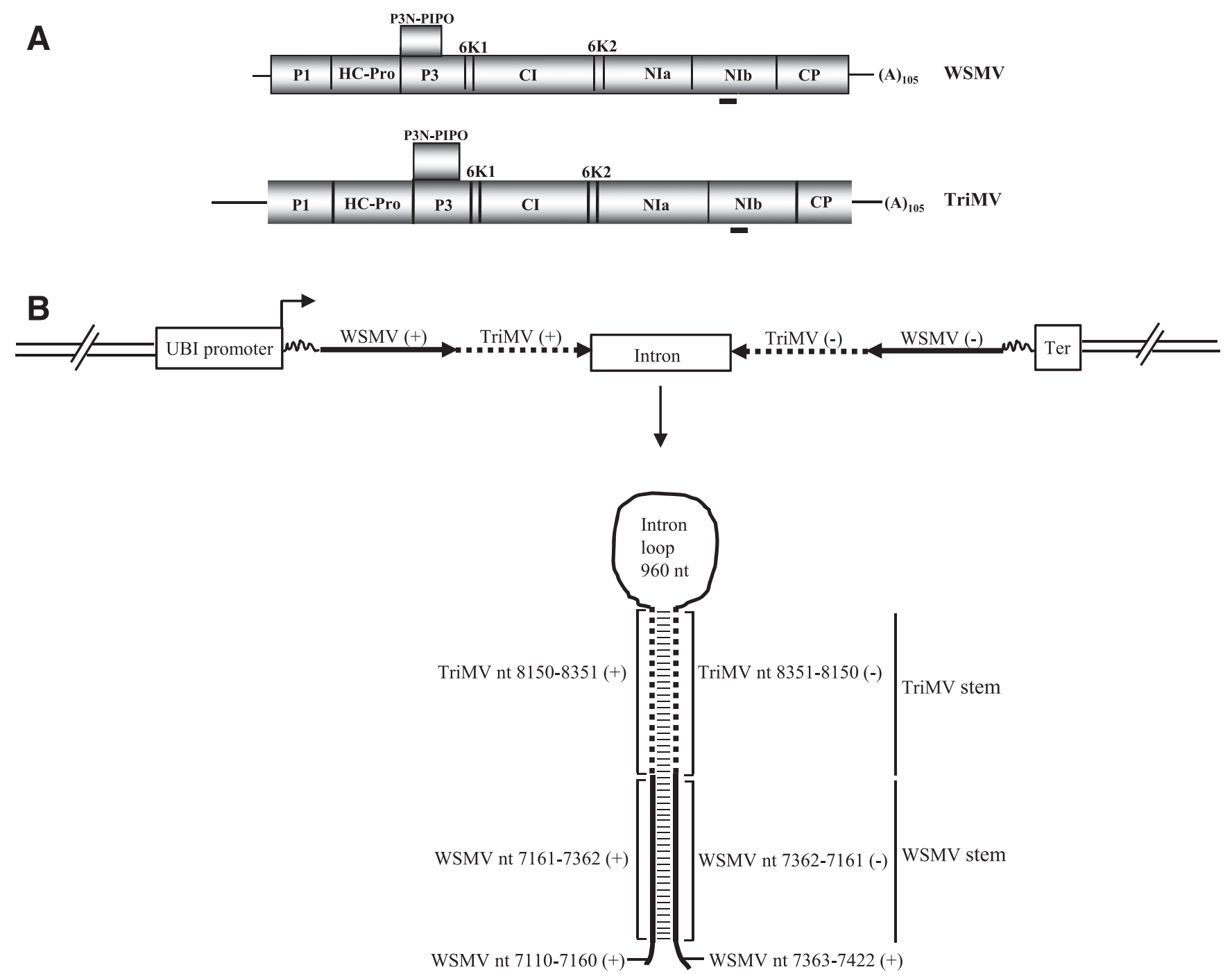

Fig. 1. Schematic diagrams showing the genome organization of wheat streak mosaic virus (WSMV) and triticum mosaic virus (TriMV) and the expression cassette of a transgene. A, The large open reading frames in the genomes of WSMV and TriMV are shown as large rectangles with encoded proteins. The locations of P3N-PIPO and of the sequence used for engineering hairpin construct are shown above and below the genomes, respectively. $\mathbf{B}$, The expression cassette showing the ubiquitin promoter, followed by the plus-sense sequence of WSMV (curved line and solid forward arrow) and TriMV (dotted forward arrow), intron sequence, minus-sense sequence of TriMV (dotted reverse arrow) and WSMV (solid reverse arrow), plus-sense sequence of WSMV (curved line), and nopaline synthase terminator (ter) sequence. A bent arrow shows the location of the transcription start site of the ubiquitin promoter. The depicted hairpin structure resulted from transcription and is shown below the expression cassette. The nucleotide coordinates of WSMV and TriMV that form a stem and free plus-sense RNA of WSMV on either side of the stem are indicated. The plus- and minus-sense RNAs of WSMV and TriMV are separated by an intron that forms a loop. 
2009; Lu et al. 2011) in Great Plains-adapted wheat cultivars. Wsml, a single dominant resistance gene present in wheat cv. Mace, was originally transferred from intermediate wheatgrass [Thinopyrum intermedium (Host) Barkworth \& D. R. Dewey] (Graybosch et al. 2009). Wsm2, a single dominant resistance gene of unknown origin, was identified in the wheat germplasm line CO960293-2 (Haley et al. 2002) and has been incorporated into wheat cultivars such as Snowmass (Haley et al. 2011) and RonL (Seifers et al. 2007). However, the Wsml and Wsm 2 genes are temperaturesensitive, with Wsml conferring high levels of resistance to WSMV and TriMV and $W s m 2$ to WSMV at $\leq 18^{\circ} \mathrm{C}$. Wheat cultivars with the Wsml or Wsm2 genes become increasingly susceptible as temperature rises above $18^{\circ} \mathrm{C}$, with complete resistance breakdown at $25^{\circ} \mathrm{C}$ or above (Graybosch et al. 2009; Haley et al. 2011; Seifers et al. 2007; Tatineni et al. 2010, 2016).

Transgenic wheat resistant to WSMV was developed with a transgene expressing either a 386-bp hpRNA comprising the coat protein (CP) (Cruz et al. 2014) or a 696-bp hpRNA involving the nuclear inclusion protein 'a' (NIa) genes (Fahim

\begin{tabular}{l|l|l|l|}
$\begin{array}{l}\text { A } \\
\text { Event \# }\end{array}$ & $\begin{array}{l}\text { Transgenic } \\
\text { wheat event Id }\end{array}$ & $\begin{array}{l}\text { No. of seedlings infected/ } \\
\text { No. of seedling inoculated }\end{array}$ \\
\hline WSMV & TriMV \\
\hline- & CB037 & $12 / 12$ & $13 / 13$ \\
\hline 1 & NN792-5-1 & $5 / 10^{1}$ & $9 / 11^{2}$ \\
\hline 2 & NN792-5-2 & $10 / 10$ & $8 / 10$ \\
\hline 3 & NN792-5-3 & $10 / 10$ & $9 / 9$ \\
\hline 4 & NN792-6-1 & $10 / 10^{3}$ & $6 / 10^{4}$ \\
\hline 5 & NN863-1-1 & $28 / 31$ & $27 / 27$ \\
\hline 6 & NN863-1-2 & $32 / 33$ & $36 / 36$ \\
\hline 7 & NN863-3-2 & $10 / 10$ & $11 / 12$ \\
\hline 8 & NN855-4-1 & $12 / 12$ & $12 / 12$ \\
\hline
\end{tabular}

${ }^{1}$ Five plants with no visible symptoms; four plants with strong symptoms; and one plant with mild symptoms.

${ }^{2}$ Two plants with no visible symptoms; four plants with strong symptoms; and five plants with mild symptoms.

${ }^{3}$ One plant with mild symptoms.

${ }^{4}$ Four plants with no visible symptoms; four plants with strong symptoms; and two plants with mild symptoms.

Wheat events in bold indicate that these events are resistant or tolerant to both viruses.

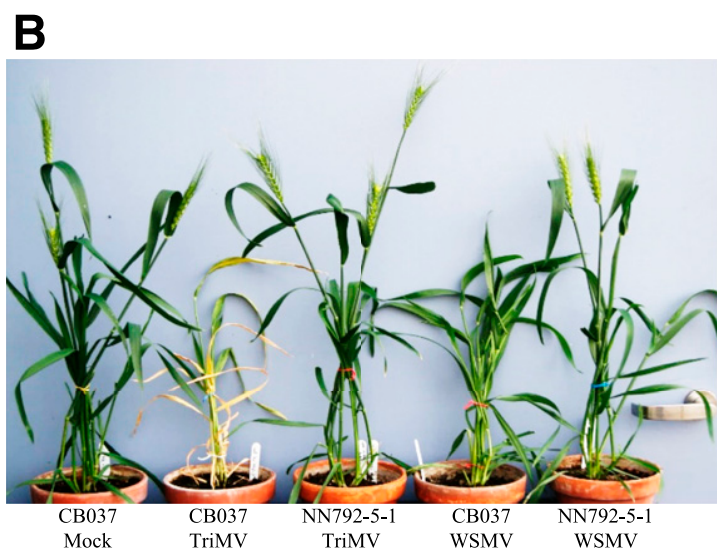

Fig. 2. Screening of $T_{1}$ wheat events for resistance against wheat streak mosaic virus (WSMV) or triticum mosaic virus (TriMV) under greenhouse conditions. A, Eight transgenic events screened for resistance against WSMV or TriMV. Numbers in red show resistance against WSMV or TriMV. Transgenic events that provided resistance against WSMV and TriMV are indicated in bold font. Note that four of eight events provided resistance against WSMV or TriMV and two events provided resistance against both viruses. B, Phenotype of wheat event NN792-5-1 inoculated with WSMV or TriMV at 40 days postinoculation. Nontransgenic spring wheat genotype CB037 was used as a control. et al. 2010). Resistance to TriMV has been reported in transgenic wheat expressing a 272-bp hpRNA from the CP gene (Shoup Rupp et al. 2016). However, a transgenic wheat with dual resistance against WSMV and TriMV is not available. The aim of this investigation is the development of dual-resistant transgenic wheat against WSMV and TriMV. Since RNAibased resistance is sequence-specific, a sequence comprising the NIb protein (replicase), one of the highly conserved regions in the WSMV and TriMV genomes, was used to assemble a hairpin element. A binary plasmid with the hpRNA element was used to transform wheat genotype CB037, and a total of eight transgenic events were obtained. Phenotyping of these transgenic wheat events for dual resistance to WSMV and TriMV resulted in the identification of two events with no detectable accumulation of virus.

Further characterization of the $\mathrm{T}_{4}$ generation dual-resistant transgenic wheat events revealed that one event provided immunity against WSMV and TriMV at temperatures $\geq 25^{\circ} \mathrm{C}$. However, the level of resistance was gradually reduced with temperatures below $25^{\circ} \mathrm{C}$. Northern blot hybridization of total RNA from dual-resistant wheat events revealed that vsRNAs accumulated at increased amounts at $32^{\circ} \mathrm{C}$ compared with those at $25^{\circ} \mathrm{C}$. In contrast, vsRNAs did not accumulate at detectable levels in both transgenic events at $20^{\circ} \mathrm{C}$. These data revealed that the resistant phenotype in RNAi-based transgenic wheat was associated with the accumulation of vsRNAs. This is the first report on developing transgenic wheat with dual resistance to synergistically interacting WSMV and TriMV.

\section{RESULTS}

Development of transgenic wheat events.

To achieve broad-spectrum resistance against WSMV and TriMV isolates, the most conserved NIb sequence among the strains of WSMV and TriMV was used for the assembly of a hpRNA element in a binary vector (Fig. 1B). The resulting pPZPUbi-WSMV-TriMV-hairpin(NIb)-NOS-T construct consists of a 202-nt plus-sense sequence from each of WSMV and TriMV, 960 nt of the small nucleolar intron sequence from Arabidopsis thaliana, followed by a 202-nt minus-sense sequence from each of TriMV and WSMV. Additionally, a spacer sequence of 51 and $60 \mathrm{nt}$ from the NIb cistron of WSMV was engineered at the upstream and downstream of hpRNA element, respectively (Fig. 1B). Thus, the hpRNA element consists of plus- and minus-sense sequence of NIb cistrons of WSMV and TriMV, separated by an intron sequence with a spacer sequence of plus sense from the NIb cistron of WSMV (Fig. 1B). The pPZP-Ubi-WSMV-TriMV-hairpin(NIb)NOS-T was used for Agrobacterium-mediated transformation of spring wheat genotype CB037, and eight nptII-positive independent events $\left(\mathrm{T}_{0}\right)$ of transformants were obtained.

\section{Characterization of transgenic wheat events.}

Progeny derived from eight independent wheat events were examined for the presence of the transgene and for virus resistance against WSMV or TriMV under greenhouse conditions. Genomic DNA (gDNA), isolated from a total of $253 \mathrm{~T}_{1}$ transgenic wheat plants, was tested for the presence of the transgenic allele by PCR, using oligonucleotides UBI-1 (5'-CGCCCGCCGT AATAAATAGA-3') and UBI-2 (5'-CCAAACCCTATGCAAC GAAAC- $3^{\prime}$ ). The number of plants that inherited the transgene was 181 of the 253 from all eight events, suggesting that the transgene was segregated, approximately, at a ratio of 3:1.

Transgenic wheat seedlings were inoculated with freshly prepared crude sap of WSMV or TriMV at 1:20 dilution in $20 \mathrm{mM}$ sodium phosphate buffer, $\mathrm{pH} 7.0$, at the two-leaf stage. All wheat seedlings from two events (NN792-5-3 and NN8554-1) were susceptible to both viruses (Fig. 2A), with the 
development of chlorotic streak and mosaic symptoms at 14 days postinoculation (dpi), as observed also on nontransgenic (NT) wheat genotype CB037. Wheat seedlings from events NN792-5-2 and NN863-3-2 were infected by TriMV in eight of 10 and 11 of 12 plants, respectively, and all inoculated plants were susceptible to WSMV (Fig. 2A). Wheat seedlings from events NN863-1-1 and NN863-1-2 were infected by WSMV in 28 of 31 and 32 of 33 plants, respectively, while none of the plants from either event provided resistance to TriMV (Fig. 2A).

Some of the wheat seedlings from events NN792-5-1 and NN792-6-1 were found to be resistant to both WSMV and TriMV (Fig. 2A). In the NN792-5-1 event, WSMV failed to infect five of 10 seedlings at detectable levels, one seedling elicited mild symptoms and four seedlings were as susceptible as the NT wheat plants. TriMV failed to infect two wheat plants of event NN792-5-1 at detectable levels, whereas five plants exhibited mild mosaic symptoms and four plants presented symptoms similar to those of NT wheat plants (Fig. 2A and B). WSMV infected 10 of 10 seedlings from event NN792-6-1, but one plant had very mild symptoms. In contrast, TriMV failed to elicit visible symptoms in four NN792-6-2 plants but elicited mild symptoms in two plants and severe symptoms in four plants (Fig. 2A). These data suggest that transgenic events
NN792-5-1 and NN792-6-1 contain wheat plants that are resistant or tolerant to both viruses. Hence, seed collected from WSMV- or TriMV-resistant or tolerant wheat plants of these two events were used for further characterization.

Seed collected from WSMV- or TriMV-resistant plants in the $\mathrm{T}_{3}$ generation (events NN792-5-1 and NN792-6-1) were further screened for stability of the resistance phenotype against WSMV, TriMV, or both under greenhouse conditions. gDNA isolated from each plant, prior to virus inoculation, was examined for the presence of the transgenic allele by PCR, with oligonucleotides UBI-1 and UBI-2. The transgenic allele in the $\mathrm{T}_{3}$ individuals of NN792-5-1 and NN792-6-1 was found in most of the wheat seedlings (Fig. 3A). From the $\mathrm{T}_{3}$ individuals carrying the transgenic allele, a $10-\mathrm{cm}$-long piece from the top fully expanded leaf per plant was collected and tested by double-antibody sandwich-enzyme-linked immunosorbent assay (ELISA) for the presence of WSMV or TriMV, at $21 \mathrm{dpi}$. Wheat seedlings from transgenic event NN792-5-1 were found to be highly resistant to either WSMV, TriMV, or both viruses with five of 88 , one of 84 , and seven of 85 of the plants infected at 21 dpi (Fig. 3B). However, NT wheat plants inoculated with WSMV or TriMV elicited chlorotic streak and mosaic symptoms with moderate stunting of plants, while coinoculated
A

$$
\begin{aligned}
& \text { Non- } \\
& \text { transgenic }
\end{aligned}
$$

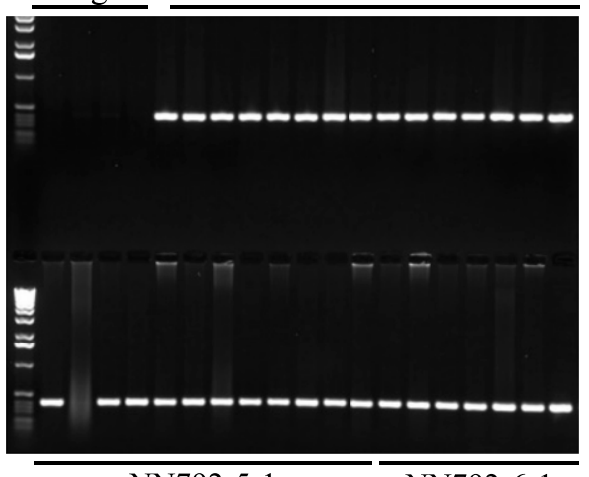

NN792-5-1

C

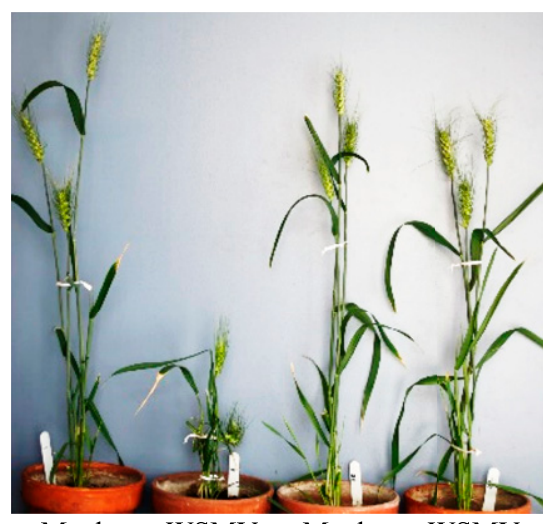

$$
\frac{\text { Mock WSMV }}{\text { CB037 }} \frac{\text { Mock WSMV }}{\text { NN792-5-1 }}
$$

\begin{tabular}{|c|c|c|c|c|c|c|}
\hline \multirow{2}{*}{$\begin{array}{l}\text { Transgenic } \\
\text { wheat event Id }\end{array}$} & \multicolumn{6}{|c|}{ No. of seedlings infected/No. of seedling inoculated } \\
\hline & WSMV & $\begin{array}{l}\% \text { of } \\
\text { infection }\end{array}$ & TriMV & $\begin{array}{l}\% \text { of } \\
\text { infection }\end{array}$ & $\begin{array}{l}\text { WSMV+ } \\
\text { TriMV }\end{array}$ & $\begin{array}{l}\% \text { of } \\
\text { infection }\end{array}$ \\
\hline CB037 & $12 / 12$ & 100 & $10 / 10$ & 100 & $12 / 12$ & 100 \\
\hline NN792-5-1 & $5 / 88$ & 6 & $1 / 84$ & 1 & $7 / 85$ & 8 \\
\hline NN792-6-1 & $10 / 11$ & 91 & $0 / 12$ & 0 & $11 / 12$ & 92 \\
\hline
\end{tabular}

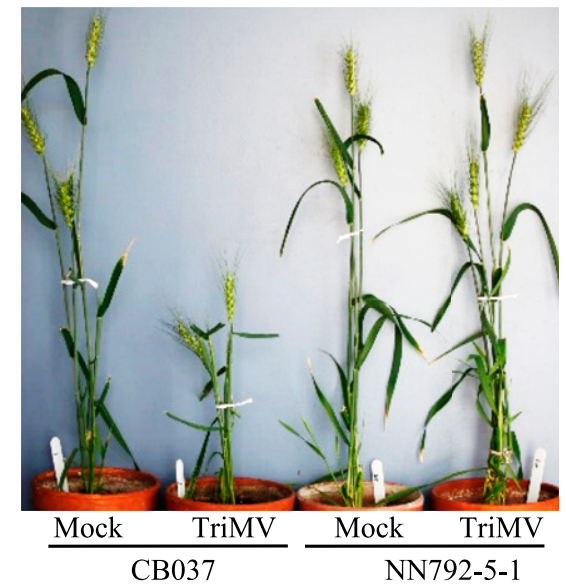

Fig. 3. Resistance screening of $T_{3}$ wheat events NN792-5-1 and NN792-6-1 against either wheat streak mosaic virus (WSMV), triticum mosaic virus (TriMV), or both under greenhouse conditions. A, Screening of transgenic wheat events NN792-5-1 and NN792-6-1 for the presence of the transgene. The genomic DNA from $\mathrm{T}_{3}$ transgenic wheat events was used for PCR amplification, with oligonucleotides UB-1 and UBI-2, for the presence of the ubiquitin promoter in the genomes of two transgenic wheat events. Ethidium bromide-stained agarose gel showing the separation of PCR-amplified products from select transgenic wheat seedlings. B, The number of plants infected compared with the number of plants inoculated and the percentage of infection. Nontransgenic wheat genotype CB037 was used as a control. C, Phenotype of T $_{3}$ wheat event NN792-5-1 inoculated with either WSMV, TriMV, or both at 54 days postinoculation. Note that plants from wheat event NN792-5-1 inoculated with WSMV, TriMV, or both are highly resistant. 
plants elicited severe chlorosis, stunting symptoms at $14 \mathrm{dpi}$, and, ultimately, plant death by $21 \mathrm{dpi}$ (Fig. 3C). In contrast, 78 of 85 coinoculated wheat plants of event NN792-5-1 did not show visible symptoms (Fig. 3C). These data indicate that event NN792-5-1 in the $T_{3}$ generation possesses dual resistance against WSMV and TriMV. Wheat plants of NN792-6-1 event ( $\mathrm{T}_{3}$ generation) inherited the transgene and were scored as moderately resistant since WSMV infected 10 of 11 plants, TriMV infected zero of 12, and WSMV+TriMV infected 11 of 12 plants at $21 \mathrm{dpi}$ (Fig. 3A and B).

\section{Seasonal effect on resistance response}

of $\mathrm{T}_{4}$ generation NN792-5-1 and NN792-6-1 lines.

Seed collected from $\mathrm{T}_{3}$ generation NN792-5-1 and NN792-6-1, hereafter referred to as T4-4 and T4-6, respectively, were tested for virus resistance, in August and October 2017, under greenhouse conditions. Wheat seedlings from T4-4 were found to be highly resistant ( 0 to $8 \%$ infection in the August test) to single or double infections with WSMV and TriMV (Table 1). However, 44 to $57 \%$ seedlings from the same T4-4 event were infected by WSMV, TriMV, or both when examined in October (Table 1). About 67 to $80 \%$ seedlings of the T4-6 event were infected by WSMV, TriMV, or both in the August test, while 91 to $92 \%$ of these plants were infected in the October test (Table 1). These data suggest that differential temperature during the months of August $\left(26\right.$ to $29^{\circ} \mathrm{C}$ maximum and 23 to $25^{\circ} \mathrm{C}$ minimum) and October ( 23 to $25^{\circ} \mathrm{C}$ maximum and 20 to $22^{\circ} \mathrm{C}$ minimum) may have contributed to the differential resistance response to WSMV and TriMV (Table 1). This observation prompted further virus resistance screening of the $\mathrm{T}_{4}$ transgenic wheat events at different temperature regimens under controlled environmental conditions.

\section{Wheat events with the hairpin transgenic allele are immune to WSMV and TriMV at $32^{\circ} \mathrm{C}$.}

The T4-4 and T4-6 wheat events were examined for virus resistance at $32^{\circ} \mathrm{C}$ in a growth chamber. NT wheat genotype CB037 and susceptible wheat cv. Tomahawk were included as controls. Wheat seedlings inoculated with WSMV, TriMV, or both were observed for symptom development at 14 and $21 \mathrm{dpi}$ and were examined for virus infection by ELISA and reverse transcription-quantitative (RT-q)PCR at $18 \mathrm{dpi}$. The ELISA test revealed that the T4-4 populations were immune to individual or dual infections, as none of the inoculated plants were found to be infected by either WSMV, TriMV, or both (Table 2; Fig. 4A, B and D). Five coinoculated T4-4 plants were randomly selected and tested for virus detection using more sensitive RT-qPCR and found that viral genomic RNA copies failed to accumulate at detectable levels (Fig. 4C). Additionally, 20 wheat cv. Tomahawk seedlings, a susceptible cultivar, were rubinoculated at the two-leaf stage with crude sap extracted from coinoculated T4-4 wheat plants at 21 dpi. None of the

Table 1. Seasonal effect on virus resistance of $\mathrm{T}_{4}$ transgenic wheat events under greenhouse conditions

\begin{tabular}{|c|c|c|c|c|c|c|c|c|c|c|c|c|}
\hline \multirow[b]{2}{*}{$\begin{array}{l}\text { Wheat } \\
\text { event }\end{array}$} & \multicolumn{6}{|c|}{ Experiment $I^{a}$} & \multicolumn{6}{|c|}{ Experiment II $^{b}$} \\
\hline & WSMV $^{\mathbf{c}}$ & $\begin{array}{c}\text { Infection } \\
(\%)\end{array}$ & TriMV $^{c}$ & $\begin{array}{c}\text { Infection } \\
(\%)\end{array}$ & $D^{d}$ & $\begin{array}{c}\text { Infection } \\
(\%)\end{array}$ & WSMV & $\begin{array}{c}\text { Infection } \\
(\%)\end{array}$ & TriMV & $\begin{array}{c}\text { Infection } \\
(\%)\end{array}$ & DI & $\begin{array}{c}\text { Infection } \\
(\%)\end{array}$ \\
\hline CB037 & $12 / 12^{\mathrm{e}}$ & 100 & $11 / 11$ & 100 & $12 / 12$ & 100 & $9 / 9$ & 100 & $9 / 9$ & 100 & $10 / 10$ & 100 \\
\hline T4-4 & $0 / 12$ & 0 & $0 / 10$ & 0 & $1 / 13$ & 8 & $4 / 9$ & 44 & $4 / 7$ & 57 & $4 / 8$ & 50 \\
\hline T4-6 & $6 / 8$ & 75 & $6 / 9$ & 67 & $8 / 10$ & 80 & $10 / 11$ & 91 & $11 / 12$ & 92 & $11 / 12$ & 92 \\
\hline
\end{tabular}

a Date of inoculation: August 26, 2017. Temperature: 26 to $29^{\circ} \mathrm{C}$ maximum, 23 to $25^{\circ} \mathrm{C}$ minimum.

b Date of inoculation: October 16,2017 . Temperature: 23 to $25^{\circ} \mathrm{C}$ maximum, 20 to $22^{\circ} \mathrm{C}$ minimum.

c Crude sap prepared at 1:20 dilution in $20 \mathrm{mM}$ sodium phosphate buffer, $\mathrm{pH}$ 7.0, from WSMV- or TriMV-infected wheat leaves.

d DI = double infection with WSMV+TriMV. Crude sap of WSMV and TriMV at 1:20 dilution was used as inoculum.

e Number of plants infected/number of plants inoculated.

Table 2. Effect of temperature on transgenic wheat resistance to wheat streak mosaic virus (WSMV), triticum mosaic virus (TriMV), or both under growth chamber conditions ${ }^{\mathrm{a}}$

\begin{tabular}{|c|c|c|c|c|c|c|}
\hline \multirow{2}{*}{$\begin{array}{l}\text { Temperature/event } \\
\text { or wheat cultivar }\end{array}$} & \multicolumn{2}{|c|}{ WSMV } & \multicolumn{2}{|c|}{ TriMV } & \multicolumn{2}{|c|}{ WSMV+TriMV } \\
\hline & Infected/inoculated & Infection (\%) & Infected/inoculated & Infection (\%) & Infected/inoculated & Infection (\%) \\
\hline \multicolumn{7}{|l|}{ At $32^{\circ} \mathrm{C}$} \\
\hline Wheat line CB037 & $12 / 12$ & 100 & $16 / 16$ & 100 & $13 / 13$ & 100 \\
\hline $\mathrm{T} 4-6$ & $1 * / 9$ & 11 & $1 * / 8$ & 13 & $2 * / 11$ & 18 \\
\hline $\mathrm{T} 4-4$ & $0 / 13$ & 0 & $0 / 12$ & 0 & $0 / 13$ & 0 \\
\hline Wheat cv. Tomahawk & $9 / 9$ & 100 & $12 / 12$ & 100 & $8 / 8$ & 100 \\
\hline \multicolumn{7}{|l|}{ At $27^{\circ} \mathrm{C}$} \\
\hline Wheat line CB037 & $12 / 12$ & 100 & $13 / 13$ & 100 & $13 / 13$ & 100 \\
\hline T4-6 & $10 / 12$ & 83 & $5 / 9$ & 56 & $11 / 14$ & 79 \\
\hline $\mathrm{T} 4-4$ & $0 / 12$ & 0 & $0 / 13$ & 0 & $0 / 10$ & 0 \\
\hline Wheat cv. Tomahawk & $12 / 12$ & 100 & $16 / 16$ & 100 & $15 / 15$ & 100 \\
\hline \multicolumn{7}{|l|}{ At $25^{\circ} \mathrm{C}$} \\
\hline Wheat line CB037 & $25 / 25$ & 100 & $27 / 27$ & 100 & $26 / 26$ & 100 \\
\hline T4-6 & $21 / 23$ & 91 & $16 / 19$ & 84 & $24 / 25$ & 96 \\
\hline $\mathrm{T} 4-4$ & $4 * / 29$ & 14 & $4 * / 29$ & 14 & $5 * / 28$ & 18 \\
\hline Wheat cv. Tomahawk & $12 / 12$ & 100 & $13 / 13$ & 100 & $7 / 7$ & 100 \\
\hline \multicolumn{7}{|l|}{ At $20^{\circ} \mathrm{C}$} \\
\hline Wheat line CB037 & $25 / 25$ & 100 & $28 / 28$ & 100 & $29 / 29$ & 100 \\
\hline T4-6 & $20 / 22$ & 91 & $25 / 25$ & 100 & $21 / 21$ & 100 \\
\hline $\mathrm{T} 4-4$ & $23 / 31$ & 74 & $27 / 27$ & 100 & $30 / 30$ & 100 \\
\hline Wheat cv. Tomahawk & $12 / 12$ & 100 & $16 / 16$ & 100 & $15 / 15$ & 100 \\
\hline
\end{tabular}

a WSMV, TriMV, and WSMV+TriMV inoculum was prepared from wheat leaves infected with WSMV or TriMV in $20 \mathrm{mM}$ sodium phosphate buffer, pH 7.0, at 1:20 dilution. Ratios indicate number of plants infected to the number of plants inoculated. An asterisk (*) indicates plants elicited mild symptoms compared with nontransgenic wheat. 


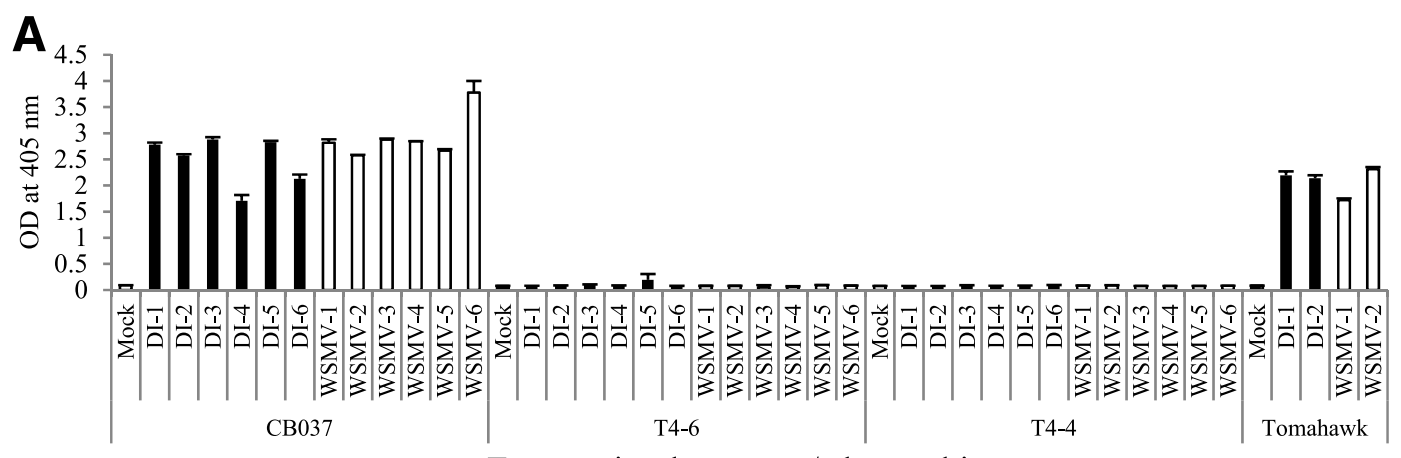

B

Transgenic wheat event/wheat cultivar

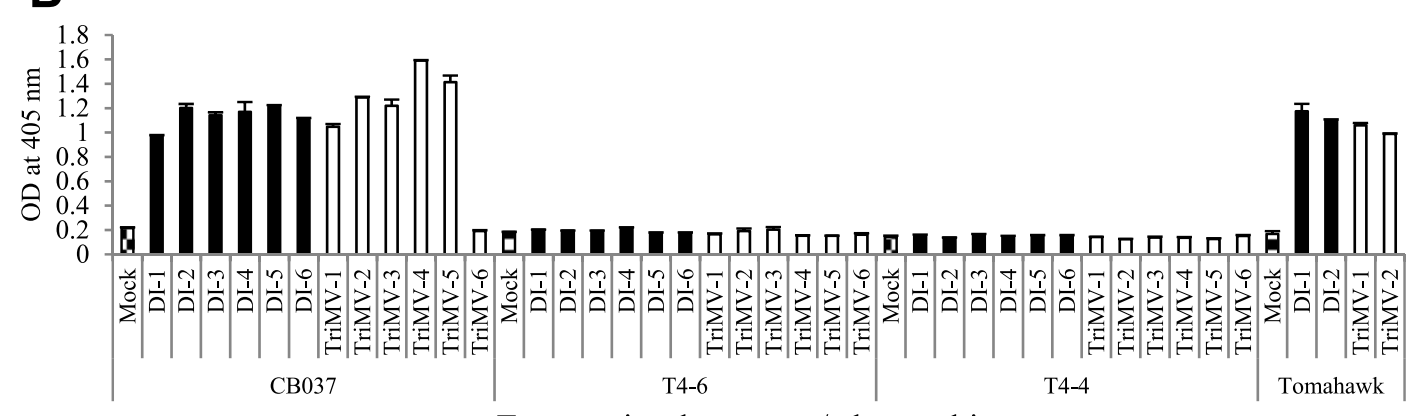

Transgenic wheat event/wheat cultivar
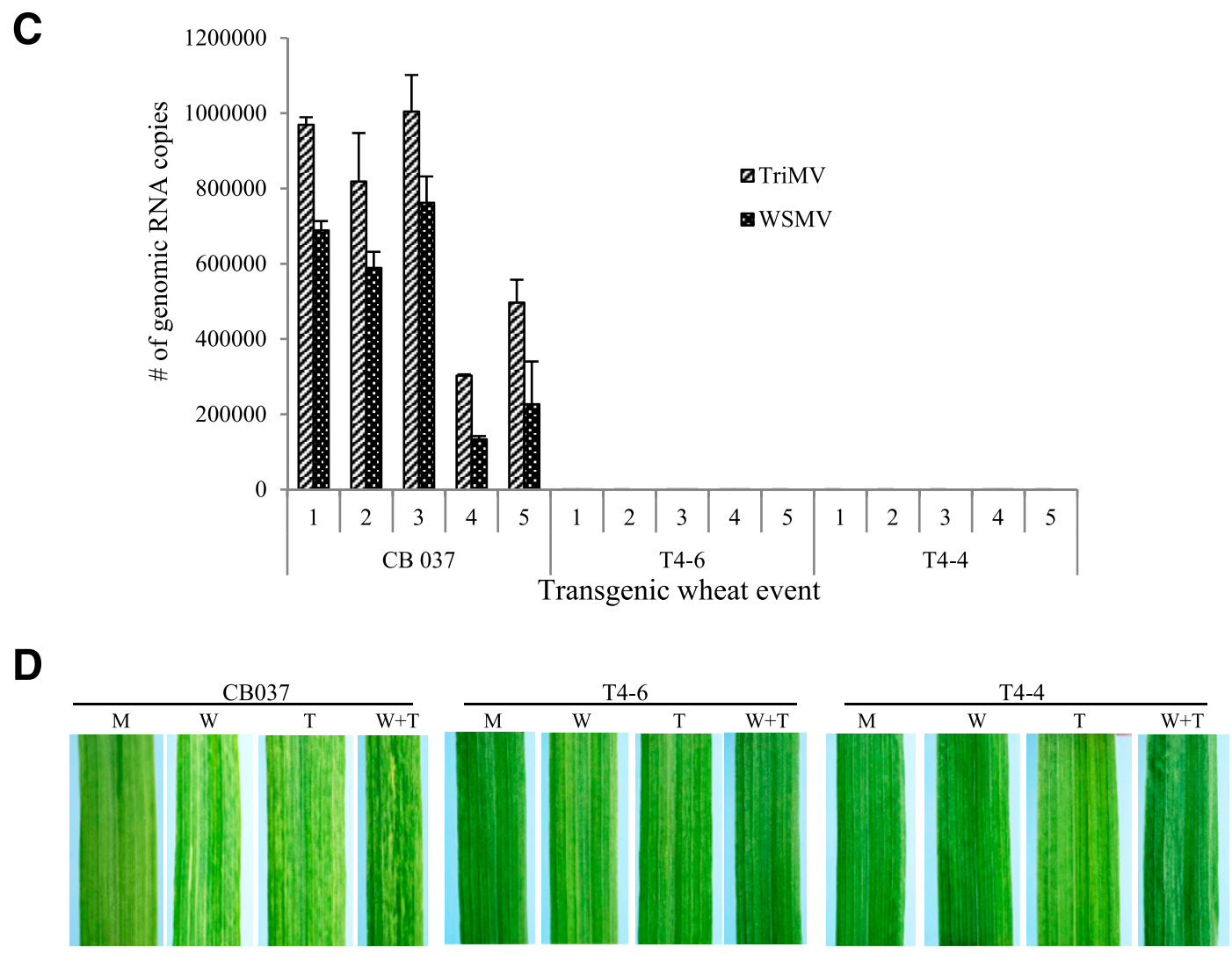

Fig. 4. The $\mathrm{T}_{4}$ generation wheat events T4-4 and T4-6 are immune to wheat streak mosaic virus (WSMV), triticum mosaic virus (TriMV), or both viruses at $32^{\circ} \mathrm{C}$. A and $\mathbf{B}$, One $10 \mathrm{~cm}$-long upper fully expanded leaf per plant was collected from inoculated plants to examine $\mathrm{T}_{4}$ transgenic wheat seedlings, inoculated with WSMV, TriMV, or both, for the presence of WSMV (A) or TriMV (B) by double-antibody sandwich-enzyme-linked immunosorbent assay (ELISA). A representative of ELISA values of six random plants are presented in the figure. C, Absolute quantification of genomic RNA copies of WSMV and TriMV per $100 \mathrm{ng}$ of total RNA in coinoculated plants at 18 days postinoculation (dpi) by reverse transcription-quantitative PCR. Total RNA was isolated from 200 mg of tissue from six select plants inoculated with WSMV+TriMV. Note that no virus accumulation was detected in T4-4 and T4-6 transgenic events. D, Symptoms on transgenic wheat events inoculated with WSMV, TriMV, or both at 21 dpi. 
Tomahawk wheat seedlings were infected at $18 \mathrm{dpi}$. These data revealed that wheat event T4-4 is immune to individual or dual virus infections by WSMV and TriMV at $32^{\circ} \mathrm{C}$.

The infection levels of wheat plants derived from the T4-6 event were $11 \%$ by WSMV, $13 \%$ by TriMV, and $18 \%$ by WSMV+TriMV, at 21 dpi (Table 2). The infected T4-6 plants exhibited milder symptoms than the NT wheat plants, suggesting that transgenic T4-6 plants are highly resistant, if not immune, to single and dual virus infections by WSMV and TriMV at $32^{\circ} \mathrm{C}$. Five coinoculated T4-6 plants with no visible symptoms and negative in the ELISA test were further examined by RT-qPCR (Fig. 4, A to C). The RTqPCR assays confirmed that virus did not accumulate at detectable levels, indicating that transgenic T4-6 populations were highly resistant to single or double infections by WSMV and TriMV. All inoculated NT wheat CB037 and Tomahawk plants were infected at 10 dpi by WSMV, TriMV, or both and were readily detected in the ELISA and RT-qPCR assays (Table 2; Fig. 4).

\section{Both transgenic wheat events are susceptible at $20^{\circ} \mathrm{C}$.}

We next examined the effect of low temperature on virus resistance of wheat events T4-4 and T4-6. At $20^{\circ} \mathrm{C}, 74$ to $100 \%$ of the T4-4 and T4-6 events were infected by WSMV, TriMV, or both, while CB037 and wheat cv. Tomahawk were readily infected at $100 \%$ (Table 2). The ELISA tests revealed that viruses were readily detected in all transgenic wheat events inoculated with individual or both viruses. However, the ELISA titers were slightly lower in the transgenics than in the NT wheat plants (Fig. 5A and B). We next examined the accumulation of genomic RNA copies of WSMV and TriMV by RTqPCR in select coinoculated plants at 18 dpi. In T4-6 plants, the genomic RNA copies of both viruses accumulated at significantly $(P<0.0001)$ reduced amounts than in NT wheat. However, in T4-4 plants, the genomic RNA copies of WSMV but not TriMV accumulated at significantly reduced levels $(P<$ 0.0001 ) compared with those in NT wheat plants (Fig. 5C). This result suggested that the presence of the transgene allele in wheat lines inhibited virus accumulation at $20^{\circ} \mathrm{C}$. Additionally, WSMV and TriMV elicited mild symptoms in single- or doubleinoculated T4-4 plants compared with NT wheat. These data suggest that both events are susceptible to WSMV and TriMV at $20^{\circ} \mathrm{C}$, but event $\mathrm{T} 4-4$ provided mild resistance, as indicated by plants exhibiting milder symptoms than those of NT wheat.

\section{Transgenic wheat event T4-4 but not T4-6 is dual-resistant at $25^{\circ} \mathrm{C}$.}

The response of transgenic wheat events T4-4 and T4-6 to single and double virus infections at $25^{\circ} \mathrm{C}$ was examined by inoculating 19 to 29 seedlings with WSMV, TriMV, or both at the two-leaf stage. These inoculations resulted in 14 to $18 \%$ wheat seedlings of event T4-4 being infected by one or both viruses, displaying milder symptoms than those of NT wheat (Table 2; Fig. 6A). In contrast, infection levels in wheat seedlings of the event T4-6 reached 84 to $96 \%$ using either WSMV, TriMV or both, with symptoms slightly milder than with NT wheat (Table 2; Figure 6A). The double-infected plants of wheat event T4-6 displayed a severe chlorotic streak, with yellowing and stunting of plants, but the symptoms were slightly less severe than those of NT wheat (Fig. 6B). In contrast, T4-4 wheat plants inoculated with both viruses did not induce symptoms, with no visible effects on heading and plant phenotype, compared with mock-inoculated plants (Fig. 6B).

ELISA assays revealed that, in single- or double-inoculated T4-4 plants, WSMV and TriMV either did not accumulate or did so at very low levels (Fig. 7A and B). In double-inoculated asymptomatic plants of T4-4, WSMV and TriMV did not accumulate at detectable levels, as seen in RT-qPCR (Fig. 7C). In wheat event T4-6, WSMV and TriMV were readily detected, in symptomatic plants, by ELISA (Fig. 7A and B), and viral genomic RNA copies accumulated in coinoculated wheat plants, except in one asymptomatic plant (Fig. 7C). These data suggest that transgenic wheat event T4-4 provided high levels of resistance against WSMV and TriMV at $25^{\circ} \mathrm{C}$, as compared with wheat event T4-6.

\section{Analysis of transgene copy number in transgenic wheat.}

The number of transgene copies in wheat events T4-4 and T4-6 was determined by using the QX200 droplet digital (dd) PCR (Fig. 8A). The ddPCR assay revealed that wheat event T4-4 plants contained a single copy of the transgene, while wheat event T4-6 plants possessed three copies integrated into the genome of wheat genotype CB037 (Fig. 8A). As expected in the NT control, no transgene was found to be integrated into the genome.

The number of loci that the transgene integrated into the wheat genome was examined by Southern blot hybridization of Sall-digested wheat gDNA. The Sall-digested gDNA of wheat event T4-4 resulted in a single band, while the T4-6 event resulted in two clear bands (Fig. 8B). These data indicate that the transgene was integrated at a single locus in the transgenic wheat event T4-4 and at two loci in T4-6.

\section{Resistance in transgenic wheat is associated with temperature-dependent accumulation of vsRNAs.}

RNAi-based transgenic resistance is dependent on accumulation of transgene-derived vsRNAs (Ding 2010; Waterhouse et al. 1998; Wesley et al. 2001). Since transgenic events T4-4 and T4-6 responded differently to virus resistance at different temperature regimens, we examined the accumulation of transgenederived 21- to 24-nt vsRNAs from these wheat events during incubation at 32,25 , and $20^{\circ} \mathrm{C}$. Total RNA isolated from these transgenic wheat plants was separated through $15 \%$ polyacrylamideTris-borate-EDTA [TBE]-urea gels, followed by hybridization with a plus-sense riboprobe specific to hpRNA.

At $32^{\circ} \mathrm{C}$, vsRNAs were readily detected in both T4-6 and T4-4 transgenic events, with a substantially higher amount of vsRNAs accumulated in T4-4 compared with T4-6 (Fig. 9, lanes 2 to 4 compared with lanes 5 to 7 ). At $25^{\circ} \mathrm{C}$, vsRNAs accumulated in wheat event T4-4 but failed to accumulate at detectable levels in transgenic event T4-6 (Fig. 9, lanes 12 to 14 compared with lanes 9 to 11 ). Interestingly, at $25^{\circ} \mathrm{C}$, vsRNAs accumulated in T4-4 plants at lowere levels than at $32^{\circ} \mathrm{C}$ (Fig. 9, lanes 12 to 14 compared with lanes 5 to 7 ). At $20^{\circ} \mathrm{C}$, vsRNAs failed to accumulate at detectable levels in both transgenic events (Fig. 9, lanes 17 to 22). The riboprobe did not hybridize with total RNA from NT wheat, suggesting it is highly specific to the hpRNA sequence (Fig. 9, lanes 1, 8, and 16). These data indicate that, for a stable resistance against WSMV and TriMV, the accumulation of vsRNAs requires a minimum temperature of $25^{\circ} \mathrm{C}$ in transgenic wheat event $\mathrm{T} 4-4$ and a minimum temperature of $32^{\circ} \mathrm{C}$ in $\mathrm{T} 4-6$. This result confirmed that posttranscriptional cleavage of hairpin transgene in wheat was responsible for dual resistance against WSMV and TriMV.

\section{DISCUSSION}

In this study, wheat events were developed that carry a transgenic allele expressing a 404-bp hpRNA element comprising the partial sequence of NIb cistrons of WSMV and TriMV in tandem. We demonstrated a method that can be used for the development of a broad-spectrum resistance against multiple viruses infecting wheat. One transgenic wheat event provided dual resistance against WSMV and TriMV, with undetectable levels of virus accumulation at temperatures above $25^{\circ} \mathrm{C}$. However, the level of dual resistance was decreased at temperatures below $25^{\circ} \mathrm{C}$. 


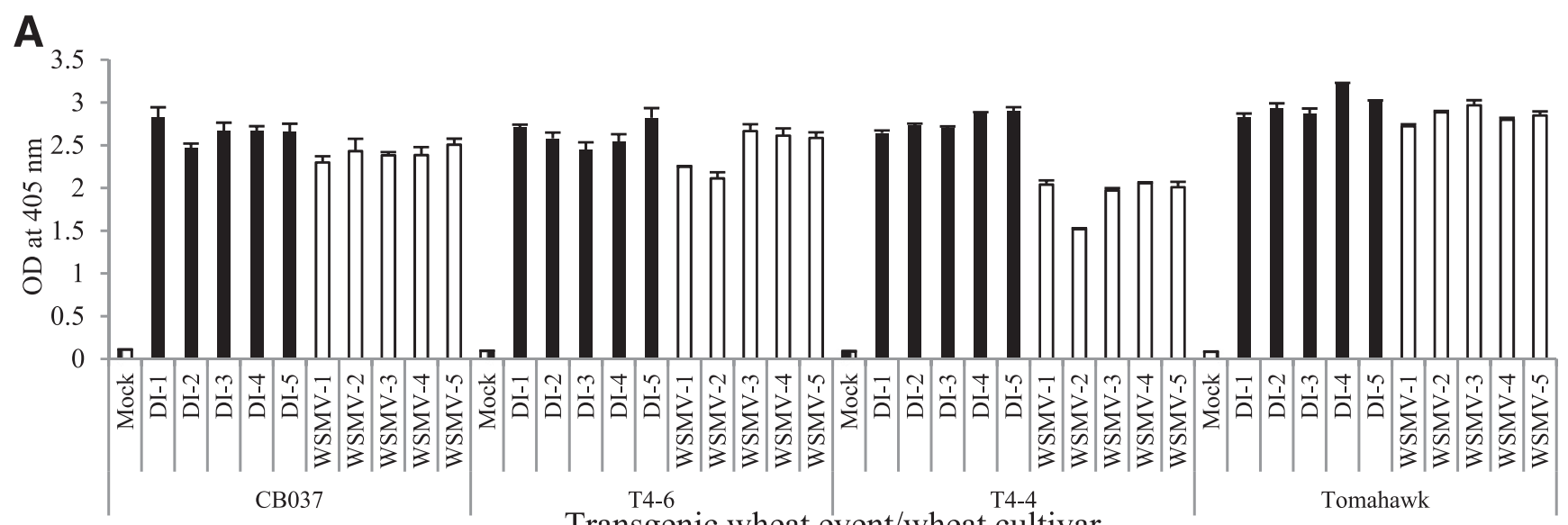

B

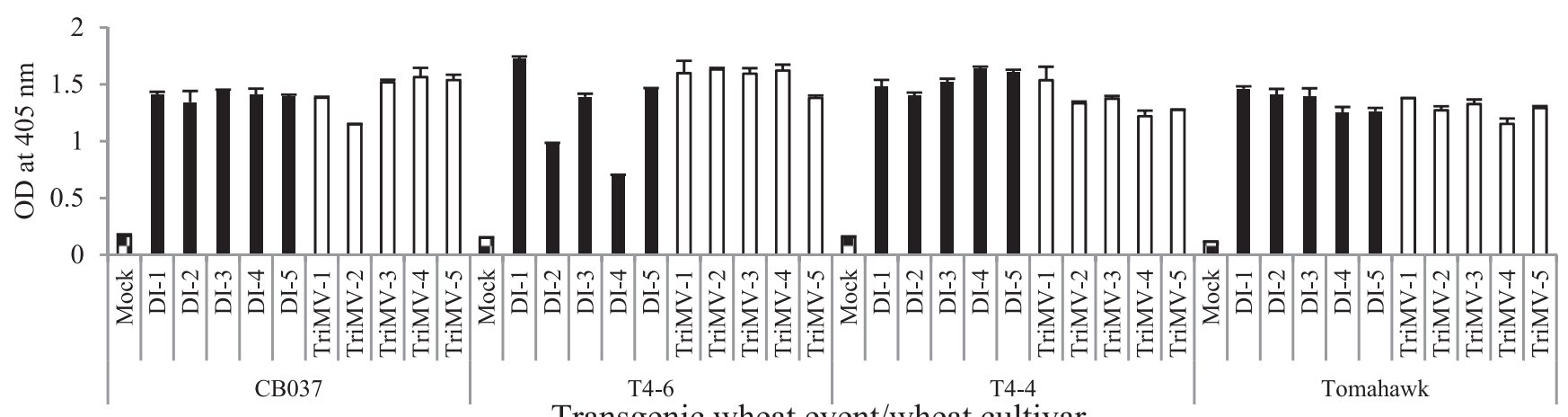

Transgenic wheat event/wheat cultivar

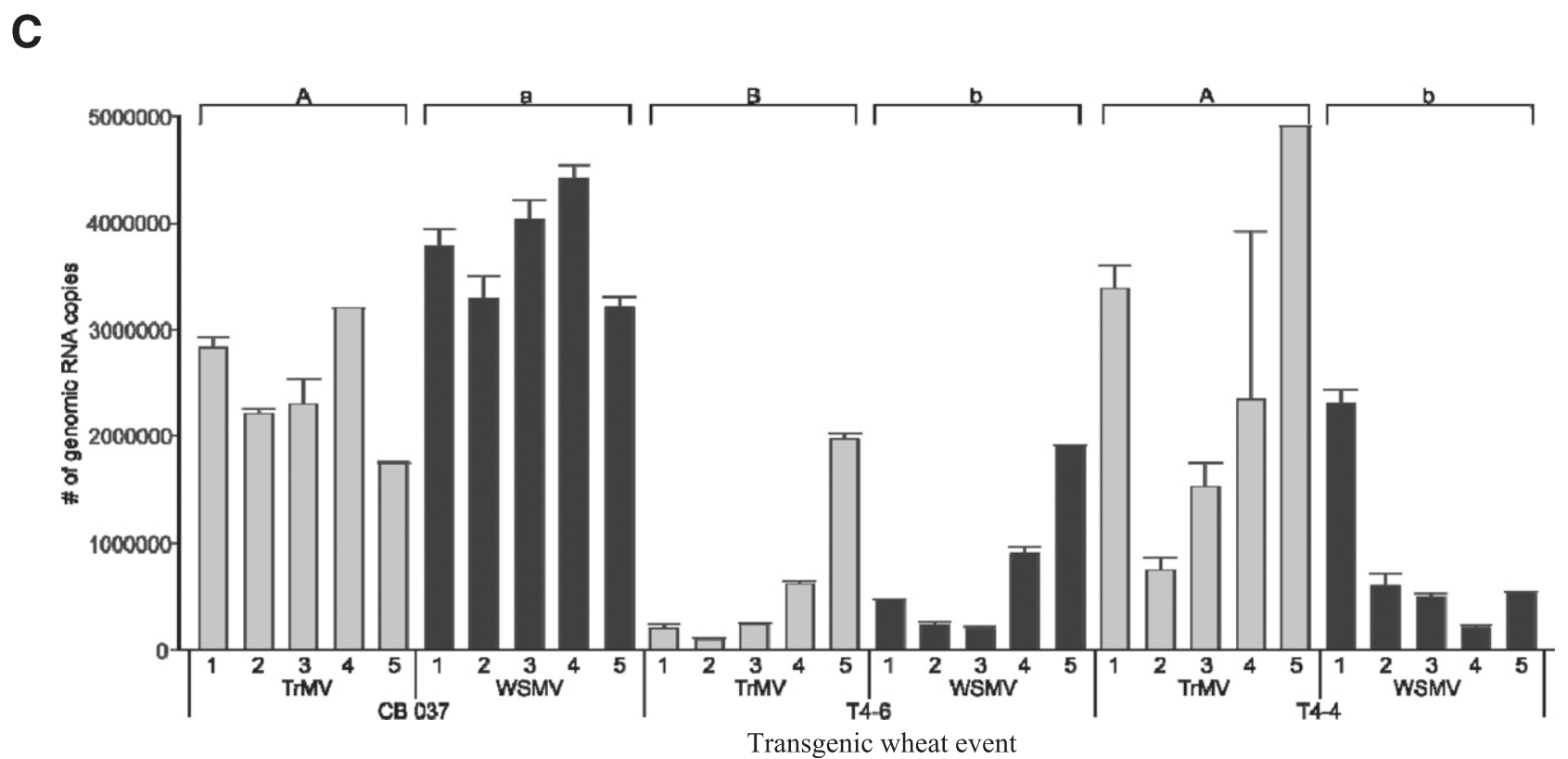

Fig. 5. The $\mathrm{T}_{4}$ transgenic wheat events are susceptible to wheat streak mosaic virus (WSMV) and triticum mosaic virus (TriMV) at $20^{\circ} \mathrm{C}$. A Detection of WSMV and $\mathbf{B}$, TriMV from single- or double-inoculated transgenic wheat events at $20^{\circ} \mathrm{C}$ with double-antibody sandwich-enzyme-linked immunosorbent assay (DAS-ELISA). A 10-cm-long leaf piece was collected from virus-inoculated wheat plants for DAS-ELISA. A representative of ELISA values of five random plants are presented in the figure. Note that all inoculated transgenic wheat plants were infected by WSMV, TriMV, or both. C, Absolute quantification of genomic RNA copies of WSMV and TriMV per $100 \mathrm{ng}$ of total RNA isolated from coinoculated wheat events. Note that WSMV and TriMV accumulated at statistically significantly lower levels compared with nontransgenic wheat genotype CB037. Viral genomic RNA copies from five biological replicates per transgenic event with two technical replicates for each were combined ( $n=30 \mathrm{WSMV}, n=30 \mathrm{TrMV}$ ) for the analysis of significance using one-way analysis of variance with posthoc Tukey honestly significant difference mean separation. Different letters above the brackets on histograms indicate significant differences between the number of WSMV or TriMV genomic RNA copies accumulated in different transgenic events at $P<0.0001$. 
Vector transmission is the principal mode of spread of plant viruses in nature and often the vectors transmit more than one virus to the same or different host plants (Whitfield et al. 2015). If the vectors transmit unrelated viruses to the same host, these viruses could potentially interact synergistically and cause severe yield losses (Mascia and Gallitelli 2016; Moreno and López-Moya 2019; Syller 2012). Synergistic interaction between WSMV and TriMV in winter wheat with increased yield losses has been reported in grower fields (Burrows et al. 2009; Byamukama et al. 2012, 2014; Fuentes-Bueno et al. 2011). Hence, wheat cultivars with dual resistance are most desirable for the management of wheat curl mite-transmitted viruses. The available genetic resistance in wheat provides temperaturesensitive dual resistance against WSMV and TriMV at $\leq 18^{\circ} \mathrm{C}$ (Graybosch et al. 2009; Haley et al. 2011; Seifers et al. 2006). Transgenic wheat events developed in this study provided dual resistance against WSMV and TriMV at $\geq 25^{\circ} \mathrm{C}$. Wheat lines with dual resistance to any wheat-infecting viruses at $18^{\circ} \mathrm{C}$ or higher have not been reported yet.

RNAi-based transgenic wheat, with the NIa or CP sequence of WSMV and CP sequence of TriMV, provided resistance against the corresponding viruses (Cruz et al. 2014; Fahim et al. 2010; Shoup Rupp et al. 2016). Additionally, transgenic wheat with complete NIb or CP cistrons of WSMV provided only moderate resistance (Sivamani et al. 2000, 2002). In latter transgenic wheat, mRNAs of transgenes and their corresponding proteins did not accumulate at detectable levels, suggesting that the observed moderate resistance in these transgenic wheat lines is most likely due to an RNAi-based phenomenon. Among the strains of WSMV, the NIb cistron is the most conserved compared with NIa and CP cistrons; particularly, the N-terminal portion of $\mathrm{CP}$ possesses a hypervariable region and is dispensable for systemic infection of wheat (Aleman-Verdaguer et al. 1997; French and Stenger 2003; Tatineni et al. 2014). The complete genome sequence of multiple TriMV isolates have not been reported, except for one isolate each from Kansas and Nebraska (Fellers et al. 2009; Tatineni et al. 2009). RNAi-based resistance, targeting the conserved sequences among the strains of a virus, would provide broad-spectrum resistance against multiple strains of a virus. In this study, we used the conserved NIb sequence of WSMV and TriMV for the development of RNAi-based transgenic wheat, and this strategy can be used for the management of different strains of WSMV and TriMV. TriMV can infect wheat by itself; however, TriMV infection in grower fields was predominantly found as coinfection with WSMV (Burrows et al. 2009; Byamukama et al. 2013; FuentesBueno et al. 2011). This observation warrants the development of dual-resistant wheat against WSMV and TriMV.
A

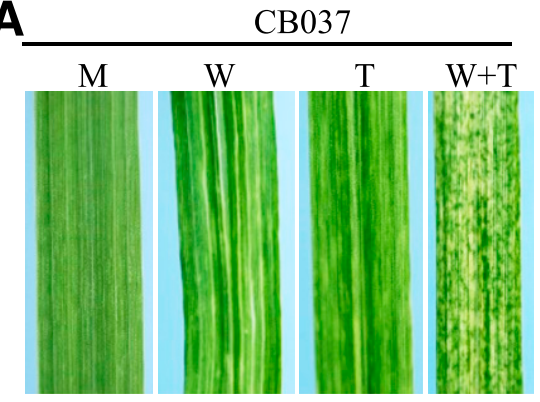

T4-6

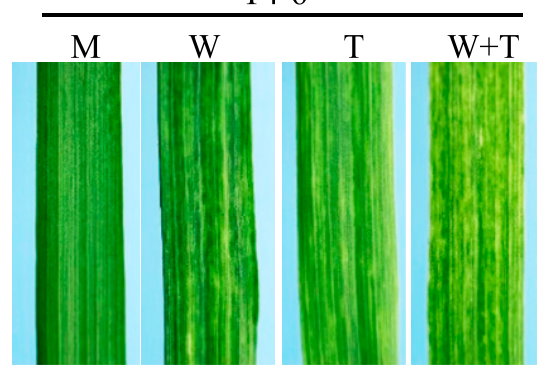

T4-4

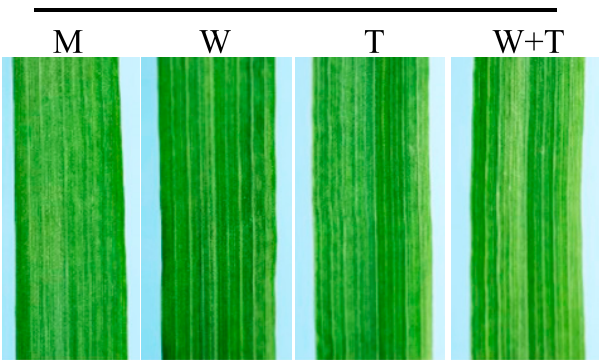

B

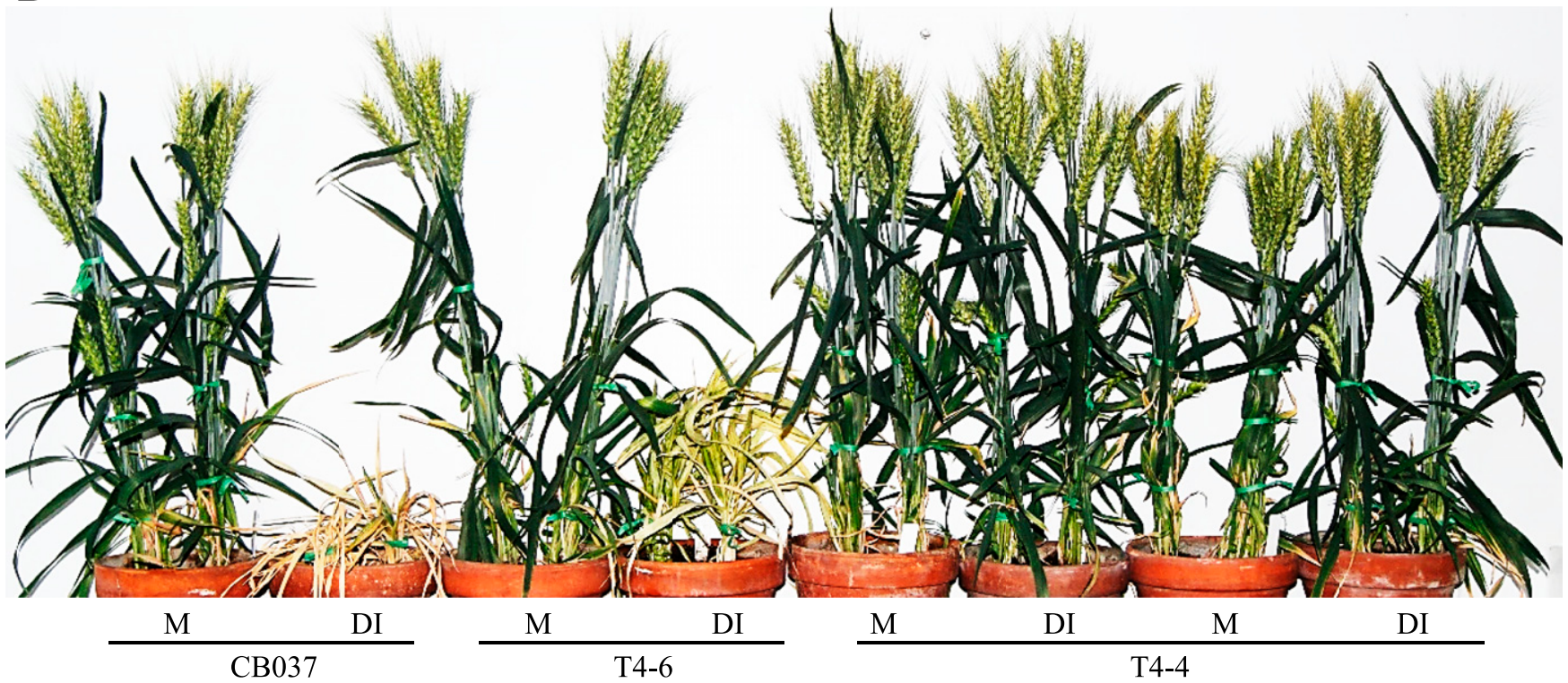

Fig. 6. Transgenic wheat event T4-4 plants are resistant to wheat streak mosaic virus (WSMV) and triticum mosaic virus (TriMV) at $25^{\circ} \mathrm{C}$ but wheat event $\mathrm{T} 4-6$ plants are not. A, Symptom phenotypes of WSMV and TriMV in single- or double-inoculated transgenic wheat events T4-4 and T4-6 at 15 days postinoculation. Note symptom development on virus-inoculated transgenic wheat event T4-6 but not on event T4-4. B, Symptom phenotypes of transgenic wheat events T4-4 and T4-6 inoculated with WSMV+TriMV showing the heads at 54 days after sowing. Note that coinoculation of WSMV+TriMV has no effect on growth and heading in wheat event T4-4 compared with those of mock-inoculated wheat. Wheat event T4-6 elicited severe stunting and leaf yellowing but slightly less stunting compared with those of nontransgenic wheat CB037. 
With the aim of obtaining dual-resistant wheat, we only chose $T_{1}$ transgenic wheat events that provided dual resistance against WSMV and TriMV for further characterization. Several lines of evidence suggest that transgenic wheat developed in this study are immune to WSMV and TriMV at $\geq 25^{\circ} \mathrm{C}$. i) Wheat plants inoculated with both viruses are symptomless, ii) both viruses did not accumulate at detectable levels in ELISA and in RT-qPCR assays, and iii) crude sap from upper noninoculated
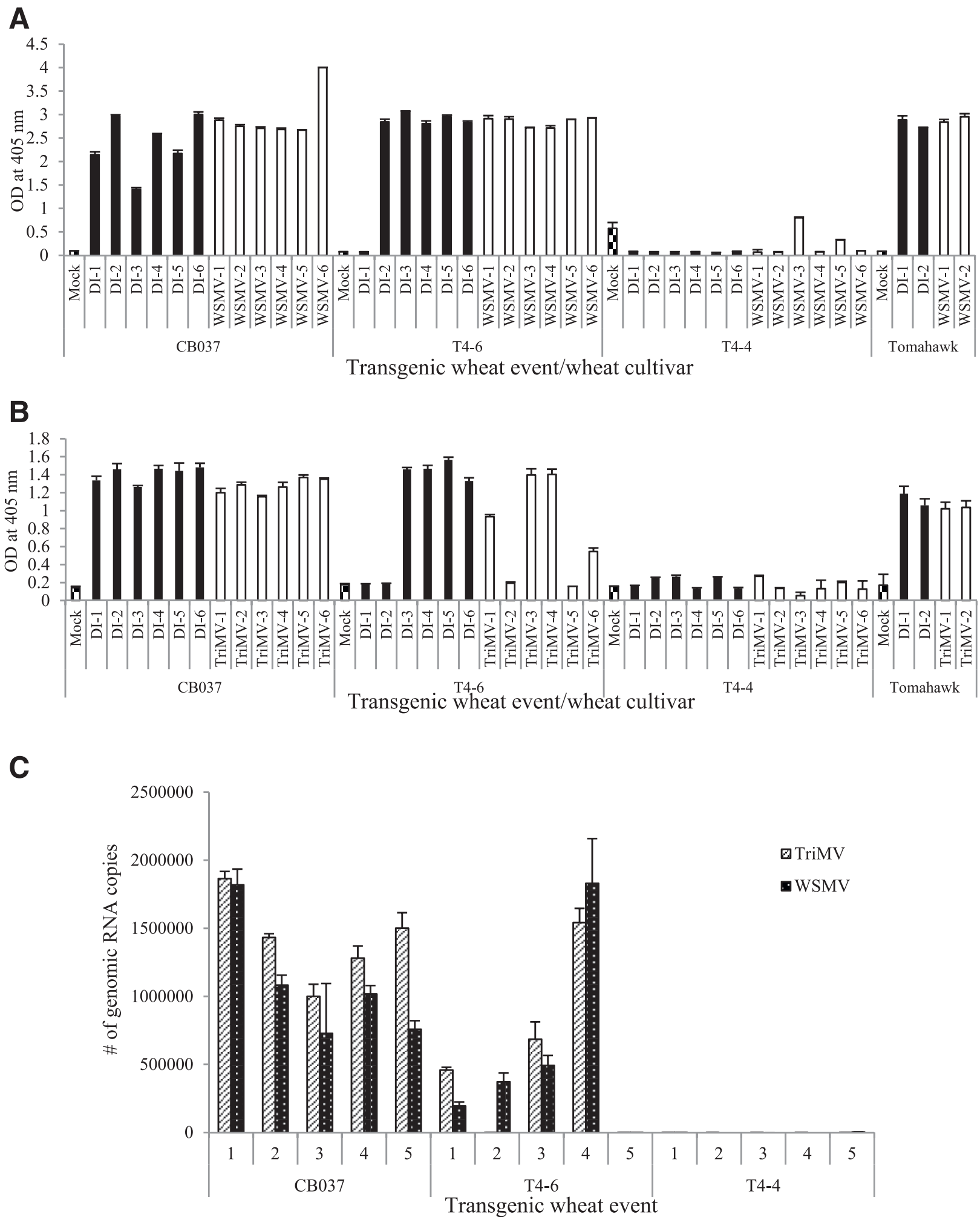

Fig. 7. Assay of transgenic wheat events inoculated with wheat streak mosaic virus (WSMV), triticum mosaic virus (TriMV), or both at $25^{\circ} \mathrm{C}$. A and $\mathbf{B}$, Doubleantibody sandwich-enzyme-linked immunosorbent assay (DAS-ELISA) of transgenic wheat events inoculated with WSMV, TriMV, or both with WSMV (A) or TriMV (B) polyclonal antibodies. One 10-cm-long leaf piece per plant from inoculated plants were tested by DAS-ELISA. A representative of ELISA values of six random plants are presented in the figure. Wheat cultivar Tomahawk was included as a susceptible control in virus assays. C, Reverse transcriptionquantitative PCR analysis of genomic RNA copies of WSMV or TriMV per $100 \mathrm{ng}$ of total RNA in coinoculated transgenic wheat events. Note that no detectable levels of genomic RNA copies of WSMV or TriMV accumulated in the coinoculated transgenic wheat event T4-4, while reduced levels of genomic RNA copies accumulated in three of four symptomatic plants and no genomic RNA copies accumulated in an asymptomatic plant of the transgenic event T4-6. 
leaves of inoculated transgenic wheat plants was not infectious on wheat seedlings following rub inoculation. However, the level of resistance decreased at temperatures below $25^{\circ} \mathrm{C}$ with $100 \%$ of plants infected with dual viruses at $20^{\circ} \mathrm{C}$. We hypothesized that the low temperature-sensitive nature of transgenic resistance found in wheat in this study could be due to temperature-dependent accumulation of vsRNAs. Northern blot hybridization of total RNA from noninoculated transgenic wheat revealed that vsRNAs accumulated at readily detectable levels in T4-4 and T4-6 transgenic events at $32^{\circ} \mathrm{C}$. The enhanced accumulation of vsRNAs in T4-4 transgenic event provided immunity to dual virus infection compared with reduced levels of vsRNA accumulation in the T4-6 transgenic event that were associated with 11 to $18 \%$ infection. The slightly reduced level of resistance of transgenic event T4-4 at $25^{\circ} \mathrm{C}$ was associated with a reduced level of vsRNAs compared with those at $32^{\circ} \mathrm{C}$. No detectable levels of vsRNAs accumulation at $25^{\circ} \mathrm{C}$ from the T4-6 transgenic event confirmed the susceptible nature of the T4-6 transgenic event with 84 to $96 \%$ infection. vsRNAs did not accumulate at detectable levels in either transgenic event at $20^{\circ} \mathrm{C}$, ascertaining the lack of resistance of these transgenic

\begin{tabular}{lll} 
A & Estimated \\
\hline $\begin{array}{l}\text { Transgenic wheat } \\
\text { event }\end{array}$ & $\begin{array}{l}\text { ddPCR Copy } \\
\text { number }\end{array}$ & $\begin{array}{l}\text { copy } \\
\text { number }\end{array}$ \\
\hline CB037 & $0.008 \pm 0.004$ & 0 \\
\hline NN792-5-1:T4-4 & $1.021 \pm 0.006$ & 1 \\
\hline NN792-6-1:T4-6 & $3.473 \pm 0.129$ & 3 \\
\hline
\end{tabular}

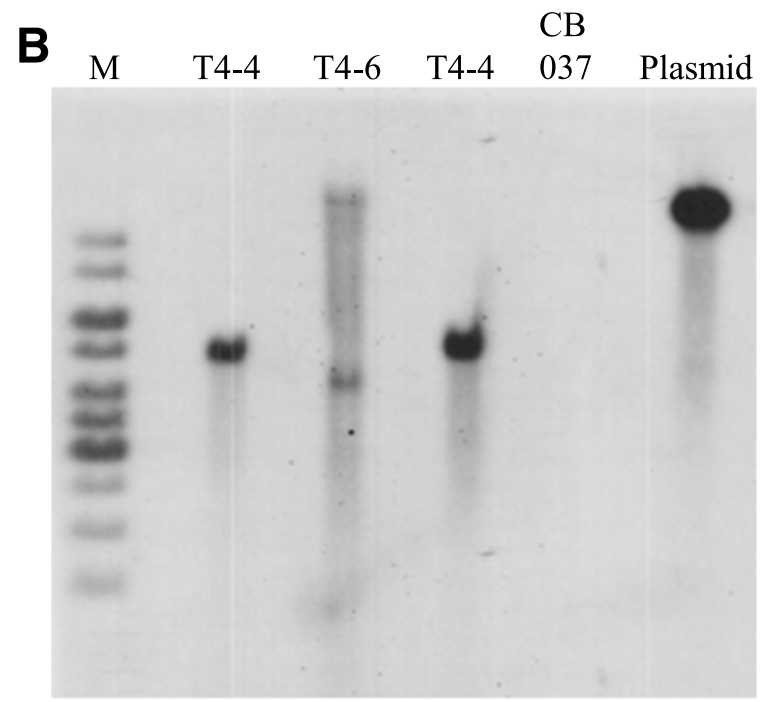

Fig. 8. Determination of the number of transgene copies in transgenic wheat events T4-4 and T4-6. A, The number of transgene copies integrated into the wheat genome was determined using the droplet digital PCR method. The transgene copy number was estimated based on relative abundance of transgene compared with the reference gene. Data presented are averages of two different plants with two technical repeats. B, Southern blot hybridization of genomic (g)DNA (approximately $30 \mu \mathrm{g}$ ) isolated from transgenic wheat events T4-4 and T4-6 and nontransgenic wheat genotype CB037. The gDNA was digested with SalI restriction enzyme and was probed with an approximately $1,600-b p$ PCR-generated ${ }^{32} \mathrm{P}$ probe covering the partial WSMV-TriMV stem and the intron. pPZP-Ubi-WSMV-TriMV-hairpin(NIb)NOS-T was used as a positive control (plasmid) in Southern blot hybridization. $\mathrm{M}=1.0 \mathrm{kbp}$ DNA marker. events at $20^{\circ} \mathrm{C}$. These data revealed that the resistant phenotype in RNAi-based transgenic wheat was underpinned by the accumulation of vsRNAs. In RNAi-based transgenic tobacco plants, resistance to cucumber mosaic virus is dependent on the accumulation of hpRNA-derived vsRNAs (Kalantidis et al. 2002).

Alternatively, it is also possible that the level of resistance is due to virus concentration at different temperatures. In NT wheat plants incubated at $27^{\circ} \mathrm{C}$, genomic RNA copies of WSMV and TriMV accumulated at similar or slightly lower levels as at $32^{\circ} \mathrm{C}$ (Table 3). However, the wheat line T4-6 is more susceptible to infection at $27^{\circ} \mathrm{C}$ than at $32^{\circ} \mathrm{C}$ (Table 2). These data further suggest that the level of resistance in transgenic wheat is proportionately related to an accumulation of vsRNAs and not to virus concentration. It has been shown that low temperatures inhibit accumulation of transgene-derived vsRNAs due to inactivation of nonessential RNA-silencing machinery with normal microRNA-mediated regulatory functions for normal plant growth (Finnegan et al. 1998; Szittya et al. 2003). As a consequence, transgenic plants become increasingly susceptible at low temperatures, and the threshold temperature for a transgenic RNAi resistance phenotype will depend on the quantity of vsRNAs produced at a specific temperature. Thus, if transgenes were programmed with generation of increased levels of vsRNAs at lower temperatures, it is likely possible that transgenic plants can provide resistance at lower temperatures.

It is puzzling why wheat plants with three transgene copies in transgenic event T4-6 are more susceptible compared with those with a single copy transgene containing T4-4 plants. These data suggest that transgene copy number is not a critical determining factor in terms of resistance and other factors, such as location of the transgene integration into wheat chromosomes, may also play an important role in providing transgenic resistance. Determining the location of the transgene in transgenic wheat events T4-6 and T4-4 is beyond the scope of the present investigation.

Wheat curl mite is the primary natural vector of both WSMV and TriMV, and vector transmission plays an important role in wheat streak mosaic disease epidemiology under ideal environmental conditions, such as initial virus inoculum and temperature (Navia et al. 2013). Transgenic wheat with a hpRNA element can prevent wheat streak mosaic disease epidemics under ideal conditions (temperatures $\geq 25^{\circ} \mathrm{C}$ ). At $20^{\circ} \mathrm{C}$, both WSMV and TriMV accumulated at substantially lower levels in transgenic wheat compared with NT plants, suggesting that use of transgenic wheat at $20^{\circ} \mathrm{C}$ could potentially minimize the efficiency of wheat curl mite transmission and, ultimately, disease epidemics.

The low temperature-sensitive nature of the transgene efficacy would limit the use of current transgenic wheat lines for the management of WSMV and TriMV diseases. However, these wheat lines can be used for gene stacking with high temperature-sensitive wheat cultivars containing natural resistance genes to obtain resistance under a wider range of temperature regimens. The Wsml- and Wsm2-containing wheat cultivars provide complete resistance at temperatures below $18^{\circ} \mathrm{C}$, moderate resistance up to $22^{\circ} \mathrm{C}$, and a complete breakdown in resistance at $25^{\circ} \mathrm{C}$ or higher. The availability of low temperature-sensitive transgenic wheat lines with dual resistance would facilitate the development of dual virus-resistant wheat lines for a broad range of temperatures by pyramiding the RNAi transgene with Wsm1 or Wsm2 or both. Stacking the transgene with Wsm1 or Wsm 2 genes is in progress, and we currently have an $\mathrm{F}_{2}$ generation of wheat lines stacked with both the transgene and Wsm1 or Wsm2 genes. Successful development of transgenic wheat events with dual resistance demonstrates that the transgene with a hpRNA element from multiple viruses could facilitate the development of wheat lines with a broad-spectrum 
resistance against economically important viruses such as WSMV, barley yellow dwarf virus, TriMV, and High Plains wheat mosaic virus in the Great Plains region of the United States.

\section{MATERIALS AND METHODS}

\section{Generation of hairpin construct.}

The maize ubiquitin promoter was PCR-amplified with engineered PstI and BamHI restriction sites at the $5^{\prime}$ and $3^{\prime}$ ends of the regulatory regions, respectively, using plasmid pLZ03 as a template (Christensen and Quail 1996; Zhang et al. 2001). The PCR-amplified product was ligated into pUC119 between PstI and BamHI sites to obtain pLA41-Ubi.

The expression cassette WSMV-TriMV-hairpin(NIb)-NOS-T was synthesized in vitro at GenScript (Piscataway, NJ, U.S.A.) with BamHI and KpnI restriction sites at the $5^{\prime}$ and $3^{\prime}$ ends, respectively. The expression cassette consists of the plus-sense sequence of nt 7,110 to 7,362 of WSMV and nt 8,150 to 8,351 of TriMV, $960 \mathrm{nt}$ of small nucleolar intron of $A$. thaliana, minus-sense sequence of $\mathrm{nt}$ 8,351 to 8,150 of TriMV and nt 7,362 to 7,161 of WSMV, and plussense sequence of nt 7,363 to 7,422 of WSMV, followed by a nopaline synthase terminator. The in vitro-synthesized WSMVTriMV-hairpin(NIb)-NOS-T was digested with BamHI and KpnI and was subcloned into similarly digested pLA41-Ubi to obtain pLA41Ubi-WSMV-TriMV-hairpin(NIb)-NOS-T.

Finally, the expression cassette with ubiquitin promoter and NOS-T was released by digesting pLA41-Ubi-WSMV-TriMVhairpin(NIb)-NOS-T with PstI and KpnI, followed by ligation into a similarly digested binary vector pPZP212 (Hajdukiewicz et al. 1994) to obtain pPZP-Ubi-WSMV-TriMV-hairpin(NIb)NOS-T. Both strands of pPZP-Ubi-WSMV-TriMV-hairpin(NIb)NOS-T were sequenced for confirmation that no unintended mutations were present in the sequence.

\section{Wheat transformation.}

Immature embryos of spring wheat genotype CB037, isolated at approximately 14 days postanthesis, were used for agrobacterium-based transformation, as described in Clemente and Mitra (2004). Monitoring of transformants for the presence of the transgenic allele was performed with ELISA, using a nptII assay (Agdia, Elkhart, IN, U.S.A.). The binary vector pPZP212 contains the nptII gene driven under a cauliflower mosaic virus $35 \mathrm{~S}$ promoter and terminated by the nos gene (Hajdukiewicz et al. 1994).
Analysis of the transgenic allele in wheat.

Total gDNA was isolated from $100 \mathrm{mg}$ of young leaf tissue of wheat seedlings using a DNeasy plant mini kit (Qiagen, Germantown, MD, U.S.A.). The presence of the transgenic allele was monitored by amplifying part of the ubiquitin promoter region using forward (UBI-1) and reverse (UBI-2) oligonucleotides. The following conditions were used for polymerase chain reaction (PCR): $95^{\circ} \mathrm{C}$ for $2 \mathrm{~min}$ for an initial denaturation step, and 35 cycles at $95^{\circ} \mathrm{C}$ for $30 \mathrm{~s}, 52^{\circ} \mathrm{C}$ for $30 \mathrm{~s}$, and $72^{\circ} \mathrm{C}$ for $45 \mathrm{~s}$, followed by a single cycle at $72^{\circ} \mathrm{C}$ for $5 \mathrm{~min}$. PCR products $(5 \mu \mathrm{l})$ were analyzed on $1.0 \%$ agarose gels in $1 \times$ Tris-acetate-EDTA buffer.

\section{Phenotyping of transgenic wheat events for virus resistance.}

Phenotyping of the $T_{1}, T_{2}$, and $T_{3}$ wheat populations, derived from the respective transgenic events, was carried out by sowing seed in a tray containing 48 blocks. Phenotyping of the $\mathrm{T}_{4}$ populations was performed in 15 -cm earthen pots by sowing 12 to 20 seeds per pot. Wheat plants were incubated in growth chambers at $32,27,25$, and $20^{\circ} \mathrm{C}$ with a $16-\mathrm{h}$ photoperiod $\left(600 \mu \mathrm{mol} \mathrm{m} \mathrm{m}^{-2} \mathrm{~s}^{-1}\right)$. Wheat leaves infected by in vitro transcripts of WSMV isolate Sidney 81 (Choi et al. 1999) and TriMV isolate Nebraska (Tatineni et al. 2015) were collected and stored at $-80^{\circ} \mathrm{C}$ and were subsequently used as inoculum source for virus-resistance assays. Seedlings of transgenic wheat were rub-inoculated at the two-leaf stage with freshly

Table 3. Accumulation of genomic RNA copies of wheat streak mosaic virus (WSMV) and triticum mosaic virus (TriMV) at different temperatures in wheat genotype $\mathrm{CB} 037^{\mathrm{a}}$

\begin{tabular}{lcc}
\hline & \multicolumn{2}{c}{ Accumulation of genomic RNA copies of } \\
\cline { 2 - 3 } Temperature $^{\mathbf{b}}$ & \multicolumn{1}{c}{ WSMV } & TriMV \\
\hline $32^{\circ} \mathrm{C}$ & $4.8 \times 10^{5} \pm 1.3 \times 10^{5}$ & $7.2 \times 10^{5} \pm 1.4 \times 10^{5}$ \\
$27^{\circ} \mathrm{C}$ & $4.0 \times 10^{5} \pm 1.2 \times 10^{5}$ & $5.9 \times 10^{5} \pm 8.7 \times 10^{4}$ \\
$25^{\circ} \mathrm{C}$ & $1.1 \times 10^{6} \pm 1.2 \times 10^{5}$ & $1.4 \times 10^{6} \pm 1.4 \times 10^{5}$ \\
$20^{\circ} \mathrm{C}$ & $3.7 \times 10^{6} \pm 2.3 \times 10^{5}$ & $2.5 \times 10^{6} \pm 2.5 \times 10^{5}$ \\
\hline
\end{tabular}

a Seedlings of nontransgenic wheat genotype CB037 were inoculated at the two-leaf stage with crude sap of WSMV or TriMV at 1:20 dilution.

b Inoculated plants were incubated in growth chambers at designated temperatures.

c The genomic RNA copies of WSMV or TriMV were determined as described by Tatineni et al. (2010). The presented number of genomic RNA copies are per 100 ng of total RNA.
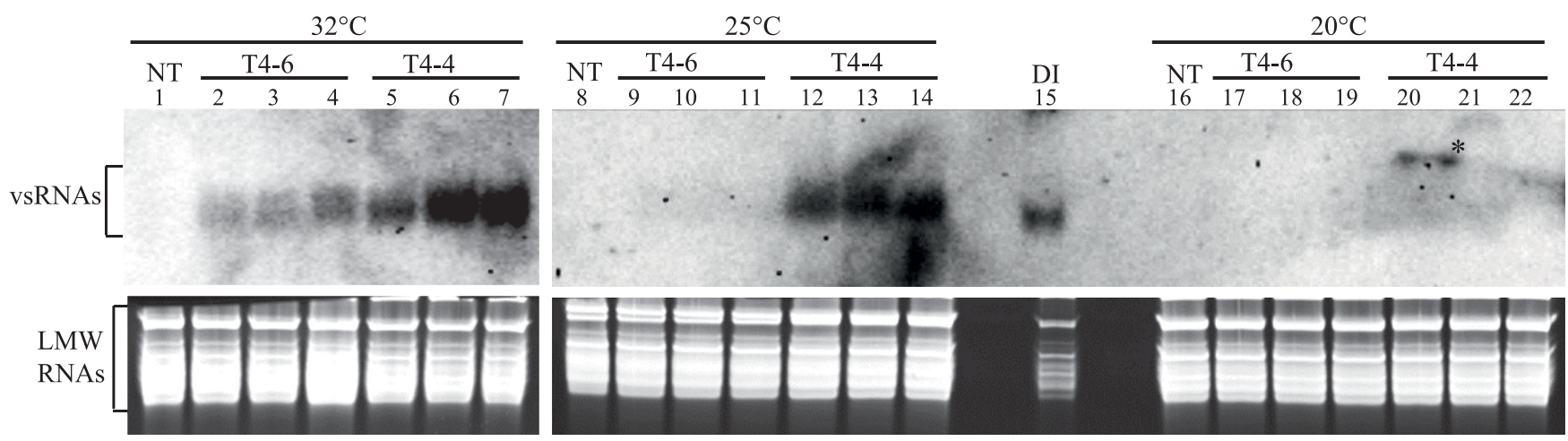

Fig. 9. The accumulation of transgene-derived virus-specific small RNAs from transgenic wheat events is temperature-dependent. Northern blot hybridization of total RNA isolated from noninoculated transgenic wheat events T4-4 and T4-6 and nontransgenic (NT) wheat incubated at 32, 25, or $20^{\circ} \mathrm{C}$. Total RNA ( $\left.30 \mu \mathrm{g}\right)$ from transgenic wheat were separated through $15 \%$ polyacrylamide-urea gels, were transferred onto nylon membrane, and were hybridized with a digoxigenin-labeled riboprobe specific to the plus-sense sequence of hairpin. All the samples were hybridized with the same riboprobe under identical conditions. Each lane represents independent extraction of total RNA isolated from a pool of two to three transgenic wheat plants. Double infection (DI), i.e., total RNA (3.0 $\mu \mathrm{g})$ isolated from wheat plants coinfected by WSMV and TriMV, was used as a positive control for vsRNA accumulation. An asterisk in the Northern blot of T4-4 samples at $20^{\circ} \mathrm{C}$ indicates an artifact band appeared between the two lanes during the process of Northern blot development. The bottom ethidium bromide-stained gels showing the low-molecular weight (LMW) RNAs as the amount of RNA loaded per lane. 
prepared crude sap of WSMV, TriMV, or WSMV+TriMV at 1:20 dilution in $20 \mathrm{mM}$ sodium phosphate buffer, $\mathrm{pH}$ 7.0. Inoculated transgenic wheat plants were observed for symptom development at 7, 9, 14, and $21 \mathrm{dpi}$.

\section{ELISA.}

Viral infections were monitored via ELISA by collecting a $10-\mathrm{cm}$ leaf piece from an upper, fully expanded noninoculated leaf from each plant into mesh bags (Agdia), stored at $-80^{\circ} \mathrm{C}$. Double antibody sandwich-ELISA was performed as described by Clark and Adams (1977), using WSMV polyclonal antibodies (Agdia) and TriMV polyclonal antibodies (Tatineni et al. 2013). ELISA plates were read at $405 \mathrm{~nm}$ and samples were considered positive if optical density at $405 \mathrm{~nm}$ was at least two times greater than mock-inoculated sample.

\section{RT-qPCR.}

Viral load in upper noninoculated leaves of transgenic wheat plants inoculated with WSMV+TriMV was estimated with RT-qPCR. Total RNA was isolated from $200 \mathrm{mg}$ of tissue from 18-dpi wheat plants, using the TriPure reagent (SigmaAldrich, St. Louis) as per the manufacturer instructions. Absolute quantification of genomic RNA copies of WSMV and TriMV was performed as described by Tatineni et al. (2010).

\section{QX200 ddPCR assay for transgene copy number.}

The number of transgene copies were determined via ddPCR in wheat events T4-4 and T4-6 as per the manufacturer protocol (Bio-Rad, Hercules, CA, U.S.A.). gDNA was isolated using a Qiagen DNA mini kit. The copy number of the transgene was estimated based on relative abundance of the transgene and of the reference gene, assuming that the transgene was at the homozygous state. The reference gene is BE406607.1, which has three copies (on chromosomes 3A, 3B, 3D) in the wheat genome (Qi et al. 2004). Data were analyzed by using Quantasoft Analysis Pro with a common signal threshold of 12,000 for all sample and primer sets. Data were averaged from two different plants as two technical repeats from each transgenic genotype.

\section{Southern analysis for number of loci determination.}

Two wheat events (T4-4 and T4-6) were used for determination of the number of loci that the transgene integrated into the wheat genome. Approximately $30 \mu \mathrm{g}$ of gDNA isolated from T4-4, T4-6, and NT wheat was digested with SalI. The digested gDNA was separated on a $0.8 \%$ agarose gel overnight at $19 \mathrm{~V}$. The resultant gel was blotted onto the nylon membrane (Bio-Rad). The probe was made using a primer, 5' ACAAAACGCGAACATTCACA-3', to amplify the DNA region with pPZP-Ubi-WSMV-TriMV-hairpin(NIb)-NOS-T as a template, covering partial WSMV-TriMV-stem and the intron (approximately $1,600 \mathrm{bp}$ ) within the gene expression cassette. The primer anneals to the positive and negative strands of the WSMV-TriMV hairpin in pPZP-Ubi-WSMV-TriMVhairpin(NIb)-NOS-T. The probe used in the hybridization step was prepared by random-prime labeling incorporating ${ }^{32} \mathrm{P}$ radiolabeled dCTP using Prime-It II kit (Agilent Technologies, Santa Clara, CA, U.S.A.). Membranes were hybridized in $0.5 \mathrm{M}$ $\mathrm{Na}_{2} \mathrm{HPO}_{4}(\mathrm{pH} 7.2$ ), $7 \%$ sodium dodecyl sulfate (SDS), $1 \%$ bovine serum albumin solution at $65^{\circ} \mathrm{C}$, overnight. Hybridized membranes were washed twice for $30 \mathrm{~min}$ in $40 \mathrm{mM} \mathrm{Na} 2 \mathrm{HPO}_{4}$ containing $5 \%$ SDS, followed by a single wash for $30 \mathrm{~min}$ in $40 \mathrm{mM} \mathrm{Na} \mathrm{HPO}_{4}$ containing $1 \% \mathrm{SDS}$ at $65^{\circ} \mathrm{C}$.

\section{Northern blot hybridization for visualization of vsRNAs.}

Seedlings of transgenic wheat events T4-4 and T4-6 and of NT wheat genotype CB037 were raised at 32,25 , and $20^{\circ} \mathrm{C}$ in growth chambers with a 16-h photoperiod $\left(600 \mu \mathrm{mol} \mathrm{m} \mathrm{m}^{-2} \mathrm{~s}^{-1}\right)$. Total RNA was extracted from $500 \mathrm{mg}$ of tissue in three biological replicates per transgenic event from young leaves at the three- to four-leaf stage, using the TriPure reagent (SigmaAldrich) as per the manufacturer instructions. Total RNA $(30 \mu \mathrm{g})$ was separated through $15 \%$ urea-polyacrylamide gels (Bio-Rad) in 1× TBE buffer, followed by transfer onto a nylon membrane (Sigma-Aldrich), and was hybridized with a digoxigenin-labeled riboprobe specific to the plus-sense stem of hairpin, as described by Tatineni et al. (2012).

\section{ACKNOWLEDGMENTS}

We thank S. Edmé for editorial assistance. We thank J. Horrell for his technical assistance. The United States Department of Agriculture (USDA) is an equal opportunity provider and employer. Mention of trade names or commercial products in this publication is solely for the purpose of providing specific information and does not imply recommendation or endorsement by the USDA. Transgenic wheat seed described in this study will be provided to interested individuals for research purpose only through a material transfer agreement with an APHIS and state permit for transgenic material.

\section{LITERATURE CITED}

Aleman-Verdaguer, M. E., Goudou-Urbino, C., Dubern, J., Beachy, R. N., and Fauquet, C. 1997. Analysis of the sequence diversity of the P1, HC, $\mathrm{P} 3, \mathrm{NIb}$ and $\mathrm{CP}$ genomic regions of several yam mosaic potyvirus isolates: Implications for the intraspecies molecular diversity of potyviruses. J. Gen. Virol. 78:1253-1264.

Baulcombe, D. 2004. RNA silencing in plants. Nature 431:356-363.

Brakke, M. K. 1987. Virus disease in wheat. Pages 585-603 in: Wheat and Wheat Improvement, 2nd ed., E. G. Heyne, ed. American Society of Agronomy, Crop Science Society of America, Soil Science Society of America, Madison, WI, U.S.A.

Burrows, M., Franc, G., Rush, C., Blunt, T., Ito, D., Kinzer, K., Olson, J., O'Mara, J., Price, J., Tande, C., Ziems, A., and Stack, J. 2009 Occurrence of viruses in wheat in the Great Plains region 2008. Plant Health Prog. 10:14.

Byamukama, E., Seifers, D. L., Hein, G. L., De Wolf, E., Tisserat, N. A., Langham, M. A. C., Osborne, L. E., Timmerman, A., and Wegulo, S. N. 2013. Occurrence and distribution of Triticum mosaic virus in the central Great Plains. Plant Dis. 97:21-29.

Byamukama, E., Tatineni, S., Hein, G. L., Graybosch, R. A., Baenziger, P. S., French, R., and Wegulo, S. N. 2012. Effects of single and double infections of winter wheat by Triticum mosaic virus and Wheat streak mosaic virus on yield determinants. Plant Dis. 96:859-864.

Byamukama, E., Wegulo, S. N., Tatineni, S., Hein, G. L., Graybosch, R. A., Baenziger, P. S., and French, R. 2014. Quantification of yield loss caused by Triticum mosaic virus and Wheat streak mosaic virus in winter wheat under field conditions. Plant Dis. 98:127-133.

Choi, I. R., French, R., Hein, G. L., and Stenger, D. C. 1999. Fully biologically active in vitro transcripts of the eriophyid mitetransmitted wheat streak mosaic tritimovirus. Phytopathology 89: 1182-1185.

Christensen, A. H., and Quail, P. H. 1996. Ubiquitin promoter-based vectors for high-level expression of selectable and/or screenable marker genes in monocotyledonous plants. Transgenic Res. 5:213-218.

Clark, M. F., and Adams, A. N. 1977. Characteristics of the microplate method of enzyme-linked immunosorbent assay for the detection of plant viruses. J. Gen. Virol. 34:475-483.

Clemente, T., and Mitra, A. 2004. Genetic Engineering of wheat: Protocols and use to enhance stress tolerance. Pages 131-163 in: Genetic Transformation in Crops. Liang, H., and Skinner, D. Z., eds. Haworth Press, NY.

Cruz, L., Shoup Rupp, J. L., Trick, H. N., and Fellers, J. P. 2014. Stable resistance to Wheat streak mosaic virus in wheat mediated by RNAi. In Vitro Cell. Dev. Biol. Plant 50:665-672.

Csorba, T., Kontra, L., and Burgyán, J. 2015. Viral silencing suppressors: Tools forged to fine-tune host-pathogen coexistence. Virology 479-480: 85-103.

Ding, S. W. 2010. RNA-based antiviral immunity. Nat. Rev. Immunol. 10: 632-644.

Ding, S. W., and Voinnet, O. 2007. Antiviral immunity directed by small RNAs. Cell 130:413-426. 
Eamens, A., Wang, M. B., Smith, N. A., and Waterhouse, P. M. 2008. RNA silencing in plants: Yesterday, today, and tomorrow. Plant Physiol. 147: 456-468.

Fahim, M., Ayala-Navarrete, L., Millar, A. A., and Larkin, P. J. 2010. Hairpin RNA derived from viral NIa gene confers immunity to wheat streak mosaic virus infection in transgenic wheat plants. Plant Biotechnol. J. 8:821-834

Fellers, J. P., Seifers, D., Ryba-White, M., and Martin, T. J. 2009. The complete genome sequence of Triticum mosaic virus, a new wheatinfecting virus of the High Plains. Arch. Virol. 154:1511-1515.

Finnegan, E. J., Genger, R. K., Peacock, W. J., and Dennis, E. S. 1998. DNA methylation in plants. Annu. Rev. Plant Physiol. Plant Mol. Biol. 49:223-247.

French, R., and Stenger, D. C. 2003. Evolution of Wheat streak mosaic virus: Dynamics of population growth within plants may explain limited variation. Annu. Rev. Phytopathol. 41:199-214.

French, R., and Stenger, D. C. 2004. Wheat streak mosaic virus. Pages 602-604 in: Viruses and Virus Diseases of Poaceae. H. Lapierre and P. Signoret, ed. INRA Editions, Paris.

Fuentes-Bueno, I., Price, J. A., Rush, C. M., Seifers, D. L., and Fellers, J. P. 2011. Triticum mosaic virus isolates in the southern Great Plains. Plant Dis. 95:1516-1519.

Gaffar, F. Y., and Koch, A. 2019. Catch me if you can! RNA silencing-based improvement of antiviral plant immunity. Viruses 11:673.

Graybosch, R. A., Peterson, C. J., Baenziger, P. S., Baltensperger, D. D., Nelson, L. A., Jin, Y., Kolmer, J., Seabourn, B., French, R., Hein, G., Martin, T. J., Beecher, B., Schwarzacher, T., and Heslop-Harrison, P. 2009. Registration of 'Mace' hard red winter wheat. J. Plant Regist. 3:51-56.

Hajdukiewicz, P., Svab, Z., and Maliga, P. 1994. The small, versatile pPZP family of agrobacterium binary vectors for plant transformation. Plant Mol. Biol. 25:989-994.

Haley, S. D., Johnson, J. J., Peairs, F. B., Stromberger, J. A., Heaton, E. E., Seifert, S. A., Kottke, R. A., Rudolph, J. B., Martin, T. J., Bai, G., Chen, X., Bowden, R. L., Jin, Y., Kolmer, J. A., Seifers, D. L., Chen, M., and Seabourn, B. W. 2011. Registration of 'Snowmass' wheat. J. Plant Regist. 5:87-90.

Haley, S. D., Martin, T. J., Quick, J. S., Seifers, D. L., Stromberger, J. A., Clayshulte, S. R., Clifford, B. L., Peairs, F. B., Rudolph, J. B., Johnson, J. J., Gill, B. S., and Friebe, B. 2002. Registration of CO960293-wheat germplasm resistant to Wheat streak mosaic virus and Russian wheat aphid. Crop Sci. 42:1381-1382.

Hamilton, A. J., and Baulcombe, D. C. 1999. A species of small antisense RNA in posttranscriptional gene silencing in plants. Science 286: 950-952.

Hammond, S. M., Bernstein, E., Beach, D., and Hannon, G. J. 2000. An RNA-directed nuclease mediates post-transcriptional gene silencing in Drosophila cells. Nature 404:293-296.

Hollandbeck, G. F., DeWolf, E., and Todd, T. 2017. Preliminary 2017 Kansas wheat disease loss estimates. Kansas Cooperative Plant Disease Survey Report. Kansas Department of Agriculture, Manhattan, KS, U.S.A. https://agriculture.ks.gov/docs/default-source/pp-disease-reports2012/2017-ks-wheat-disease-loss-estimates.pdf?sfvrsn=ce1382c1_0

Jones, R. A. C. 2006. Control of plant virus diseases. Adv. Virus Res. 67: 205-244.

Kalantidis, K., Psaradakis, S., Tabler, M., and Tsagris, M. 2002. The occurrence of CMV-specific short RNAs in transgenic tobacco expressing virus-derived double-stranded RNA is indicative of resistance to the virus. Mol. Plant-Microbe Interact. 15:826-833.

Lu, H., Price, J., Devkota, R., Rush, C., and Rudd, J. 2011. A dominant gene for resistance to Wheat streak mosaic virus in winter wheat line CO960293-2. Crop Sci. 51:5-12.

Mascia, T., and Gallitelli, D. 2016. Synergies and antagonisms in virus interactions. Plant Sci. 252:176-192.

McMechan, A. J., Tatineni, S., French, R., and Hein, G. L. 2014. Differential transmission of Triticum mosaic virus by wheat curl mite populations collected in the Great Plains. Plant Dis. 98:806-810.

Moreno, A. B., and López-Moya, J. J. 2019. When viruses play team sports: Mixed infections in plants. Phytopathology doi.org/10.1094/PHYTO07-19-0250-FI.

Navia, D., de Mendonça, R. S., Skoracka, A., Szydło, W., Knihinicki, D., Hein, G. L., da Silva Pereira, P. R. V., Truol, G., and Lau, D. 2013. Wheat curl mite, Aceria tosichella, and transmitted viruses: An expanding pest complex affecting cereal crops. Exp. Appl. Acarol. 59:95-143.

Qi, L. L., Echalier, B., Chao, S., Lazo, G. R., Butler, G. E., Anderson, O. D., Akhunov, E. D., Dvorák, J., Linkiewicz, A. M., Ratnasiri, A., Dubcovsky, J., Bermudez-Kandianis, C. E., Greene, R. A., Kantety, R., La Rota, C. M., Munkvold, J. D., Sorrells, S. F., Sorrells, M. E., Dilbirligi, M., Sidhu, D., Erayman, M., Randhawa, H. S., Sandhu, D., Bondareva, S. N., Gill, K. S., Mahmoud, A. A., Ma, X. F., Miftahudin,
Gustafson, J. P., Conley, E. J., Nduati, V., Gonzalez-Hernandez, J. L. Anderson, J. A., Peng, J. H., Lapitan, N. L., Hossain, K. G., Kalavacharla, V., Kianian, S. F., Pathan, M. S., Zhang, D. S., Nguyen, H. T., Choi, D. W., Fenton, R. D., Close, T. J., McGuire, P. E., Qualset, C. O., and Gill, B. S. 2004. A chromosome bin map of 16,000 expressed sequence tag loci and distribution of genes among the three genomes of polyploid wheat. Genetics 168:701-712.

Qu, F. 2010. Antiviral role of plant-encoded RNA-dependent RNA polymerases revisited with deep sequencing of small interfering RNAs of virus origin. Mol. Plant-Microbe Interact. 23:1248-1252.

Seifers, D. L., Martin, T. J., and Fellers, J. P. 2011. Occurrence and yield effects of wheat infected with Triticum mosaic virus in Kansas. Plant Dis. 95:183-188.

Seifers, D. L., Martin, T. J., Harvey, T. L., Fellers, J. P., and Michaud, J. P. 2009. Identification of the wheat curl mite as the vector of Triticum mosaic virus. Plant Dis. 93:25-29.

Seifers, D. L., Martin, T. J., Harvey, T. L., Fellers, J. P., Stack, J. P., RybaWhite, M., Haber, S., Krokhin, O., Spicer, V., Lovat, N., Yamchuk, A., and Standing, K. G. 2008. Triticum mosaic virus: A new virus isolated from wheat in Kansas. Plant Dis. 92:808-817.

Seifers, D. L., Martin, T. J., Harvey, T. L., and Haber, S. 2007. Temperaturesensitive Wheat streak mosaic virus resistance identified in KS03HW12 wheat. Plant Dis. 91:1029-1033.

Seifers, D. L., Martin, T. J., Harvey, T. L., Haber, S., and Haley, S. D. 2006. Temperature sensitivity and efficacy of Wheat streak mosaic virus resistance derived from C0960293 wheat. Plant Dis. 90:623-628.

Shoup Rupp, J. L., Cruz, L., Trick, H. N., and Fellers, J. P. 2016. RNAimediated, stable resistance to Triticum mosaic virus in wheat. Crop Sci. 56:1602-1610.

Sivamani, E., Brey, C. W., Dyer, W. E., Talbert, L. E., and Qu, R. D. 2000. Resistance to wheat streak mosaic virus in transgenic wheat expressing the viral replicase (NIb) gene. Mol. Breed. 6:469-477.

Sivamani, E., Brey, C. W., Talbert, L. E., Young, M. A., Dyer, W. E., Kaniewski, W. K., and Qu, R. 2002. Resistance to wheat streak mosaic virus in transgenic wheat engineered with the viral coat protein gene. Transgenic Res. 11:31-41.

Slykhuis, J. T. 1955. Aceria tulipae Keifer (Acarina: Eriophyidae) in relation to spread of wheat streak mosaic virus. Phytopathology 45: 116-128.

Stenger, D. C., Hall, J. S., Choi, I. R., and French, R. 1998. Phylogenetic relationships within the family potyviridae: Wheat streak mosaic virus and brome streak mosaic virus are not members of the genus rymovirus. Phytopathology 88:782-787.

Stenger, D. C., Young, B. A., Qu, F., Morris, T. J., and French, R. 2007. Wheat streak mosaic virus lacking helper component-proteinase is competent to produce disease synergism in double infections with Maize chlorotic mottle virus. Phytopathology 97:1213-1221.

Syller, J. 2012. Facilitative and antagonistic interactions between plant viruses in mixed infections. Mol. Plant Pathol. 13:204-216.

Szittya, G., Silhavy, D., Molnár, A., Havelda, Z., Lovas, A., Lakatos, L., Bánfalvi, Z., and Burgyán, J. 2003. Low temperature inhibits RNA silencing-mediated defence by the control of siRNA generation. EMBO J. 22:633-640.

Tatineni, S., Graybosch, R. A., Hein, G. L., Wegulo, S. N., and French, R. 2010. Wheat cultivar-specific disease synergism and alteration of virus accumulation during co-infection with Wheat streak mosaic virus and Triticum mosaic virus. Phytopathology 100:230-238.

Tatineni, S., Kovacs, F., and French, R. 2014. Wheat streak mosaic virus infects systemically despite extensive coat protein deletions: Identification of virion assembly and cell-to-cell movement determinants. J. Virol 88:1366-1380.

Tatineni, S., McMechan, A. J., Bartels, M., Hein, G. L., and Graybosch, R. A. 2015. In vitro transcripts of wild-type and fluorescent proteintagged Triticum mosaic virus (family Potyviridae) are biologically active in wheat. Phytopathology 105:1496-1505.

Tatineni, S., Qu, F., Li, R., Morris, T. J., and French, R. 2012. Triticum mosaic poacevirus enlists P1 rather than HC-Pro to suppress RNA silencing-mediated host defense. Virology 433:104-115.

Tatineni, S., Sarath, G., Seifers, D., and French, R. 2013. Immunodetection of Triticum mosaic virus by DAS- and DAC-ELISA using antibodies produced against coat protein expressed in Escherichia coli: Potential for high-throughput diagnostic methods. J. Virol. Methods 189:196-203.

Tatineni, S., Wosula, E. N., Bartels, M., Hein, G. L., and Graybosch, R. A. 2016. Temperature-dependent Wsm1 and Wsm2 gene-specific blockage of viral long-distance transport provides resistance to Wheat streak mosaic virus and Triticum mosaic virus. Mol. Plant-Microbe Interact. 29: 724-738. 
Tatineni, S., Ziems, A. D., Wegulo, S. N., and French, R. 2009. Triticum mosaic virus: A distinct member of the family potyviridae with an unusually long leader sequence. Phytopathology 99:943-950.

Waterhouse, P. M., Graham, M. W., and Wang, M. B. 1998. Virus resistance and gene silencing in plants can be induced by simultaneous expression of sense and antisense RNA. Proc. Natl. Acad. Sci. U.S.A. 95:13959-13964.

Wesley, S. V., Helliwell, C. A., Smith, N. A., Wang, M. B., Rouse, D. T., Liu, Q., Gooding, P. S., Singh, S. P., Abbott, D., Stoutjesdijk, P. A., Robinson, S. P., Gleave, A. P., Green, A. G., and Waterhouse, P. M. 2001.
Construct design for efficient, effective and high-throughput gene silencing in plants. Plant J. 27:581-590.

Whitfield, A. E., Falk, B. W., and Rotenberg, D. 2015. Insect vectormediated transmission of plant viruses. Virology 479-480: 278-289.

Zhang, L., French, R., Langenberg, W. G., and Mitra, A. 2001. Accumulation of barley stripe mosaic virus is significantly reduced in transgenic wheat plants expressing a bacterial ribonuclease. Transgenic Res. 10:13-19. 